The effect of intrafamily agency conflicts on audit demand in private family firms: The moderating role of the board of directors

Peer-reviewed author version

CORTEN, Maarten; STEIJVERS, Tensie \& LYBAERT, Nadine (2017) The effect of intrafamily agency conflicts on audit demand in private family firms: The moderating role of the board of directors. In: Journal of Family Business Strategy, 8 (1), p. 13-28.

DOI: 10.1016/j.jfbs.2017.01.003

Handle: http://hdl.handle.net/1942/23466 


\title{
The effect of intrafamily agency conflicts on audit demand in private family firms: the moderating role of the board of directors
}

\author{
Maarten Corten ${ }^{\mathrm{a}}$, Tensie Steijvers ${ }^{\mathrm{b}}$ and Nadine Lybaert $^{\mathrm{c}}$
}

\begin{abstract}
While the value of external audits was long considered to be minimal for private family firms, some exceptional studies indicate that external audits are demanded by these firms to reduce the agency conflicts between family and non-family members. Using a sample of Belgian private family firms, this study empirically shows that (high quality) auditors are also hired to mitigate agency conflicts among family members. Since these intrafamily conflicts are mainly based on emotions instead of economically rational behavior and are therefore difficult to grasp by compositional proxies, they are identified by the level of family cohesion. Moreover, this study shows that the monitoring effectiveness of the board of directors weakens the association between the level of intrafamily agency conflicts and audit (quality) demand, indicating that the audit demand effect of intrafamily agency conflicts decreases when family firms are able to reduce the related agency costs internally.
\end{abstract}

Keywords: audit demand, private family firms, intrafamily agency conflicts, family cohesion, board of directors

\footnotetext{
${ }^{\text {a }}$ Corresponding author

Hasselt University, Research Center for Entrepreneurship and Family Firms (RCEF); Research Foundation Flanders

Martelarenlaan 42, 3500 Hasselt

Belgium

maarten.corten@uhasselt.be

${ }^{\mathrm{b}}$ Hasselt University, Research Center for Entrepreneurship and Family Firms (RCEF)

tensie.steijvers@uhasselt.be
${ }^{\mathrm{c}}$ Hasselt University, Research Center for Entrepreneurship and Family Firms (RCEF); guest professor at University of Antwerp
nadine.lybaert@uhasselt.be




\section{Introduction}

Audit demand is generally explained by agency theory, which considers auditing as one of the main devices to mitigate agency conflicts. By verifying the validity of the financial statements, an auditor is considered to be able to reduce the related agency costs as this verification reduces the information asymmetries between the firm's stakeholders and therefore limits the possibilities for managers to behave opportunistically (Becker, Defond, Jiambalvo, \& Subramanyam, 1998). Based on agency theory, many studies investigating listed firms have found the level of agency conflicts to be the main driver of demanding an (high quality) audit (e.g. Fan \& Wong, 2005; Firth \& Smith, 1992; Francis, Richard, \& Vanstraelen, 2009; Francis \& Wilson, 1988; Liu \& Lai, 2012; Piot, 2001; Reed, Trombley, \& Dhaliwal, 2000).

Traditional agency theory predicts only a limited level of agency conflicts in private and especially private family firms due to more concentrated ownership and closer relationships, which already decreases the possibilities as well as the incentives for managers to behave opportunistically towards others (Fama \& Jensen, 1983a, 1983b; Jensen \& Meckling, 1976). Therefore, audit demand studies in a private (family) firm context, are scarce. However, agency problems do also occur in private family firms. First, agency conflicts can arise between family and non-family members due to different opinions regarding the firm's goals, family employment, and other issues (Schulze, Lubatkin, Dino, \& Buchholtz, 2001). This may lead to a demand for auditing in private family firms as well, which is also confirmed by some exceptional studies (Carey, Simnett, \& Tanewski, 2000; Collis, 2012; Collis, Jarvis, \& Skerratt, 2004; Niemi, Kinnunen, Ojala, \& Troberg, 2012; Niskanen, Karjalainen, \& Niskanen, 2010). Second, agency conflicts can also prevail within the family (Blanco-Mazagatos, De Quevedo-Puente, \& Castrillo, 2007; Gomez-Mejia, NuñezNickel, \& Gutierrez, 2001; Schulze et al., 2001). 
These intrafamily agency conflicts may result from the fact that family relationships are generally based on emotions and the agency theory's assumption of economically rational behavior will therefore not hold (Gomez-Mejia et al., 2001; Schulze, Lubatkin, \& Dino, 2003a; Schulze et al., 2001). Among others, potential causes of such intrafamily agency conflicts may be the protection-autonomy clash between parents and offspring, sibling rivalry or emotional conflicts between parents (Nicholson, 2008a, 2008b). For example, family members may become dissatisfied about their role in the family firm and turn jealous of other family members, which may lead to opportunistic behavior (Sharma, Chrisman, Pablo, \& Chua, 2001).

As intrafamily agency conflicts can arise in family firms, they may also increase the demand for an (high quality) auditor to reduce the related agency costs. More specifically, by verifying the financial statements, (high quality) auditors may discourage family members to behave opportunistically and 'de-emotionalize' potential conflicts by providing all family members with objective financial information that would enable them to make more rational business decisions. Therefore, we want to add to the aforementioned studies that only focused on the agency conflicts between family and non-family members by examining the relationship between the level of these intrafamily agency conflicts and audit demand.

Moreover, since one of the main roles of a firm's board of directors is monitoring and controlling management in order to reduce agency costs (Eisenhardt, 1989; Fama \& Jensen, 1983b; Zahra \& Pearce, 1989), an effective monitoring board could also be considered as an instrument on which a family firm could rely to mitigate the level of intrafamily agency costs (Bammens, Voordeckers, \& Van Gils, 2010). More specifically, effective monitoring boards will focus on providing the different family units with objective information and controlling the behavior of family managers to ensure that the interests of all family owners are being served (Bammens, Voordeckers, \& Van Gils, 2008; Bammens et al., 2010; Steier, 2001). 
Because these tasks partly overlap with the tasks of the external auditor and serve the same goal (i.e. reducing intrafamily agency costs), the demand effect of intrafamily agency conflicts on audit demand might be moderated by the monitoring effectiveness of the board. Since privacy and confidentiality are considered to be two of the most important values for family firms (Lester \& Cannella, 2006; Su \& Dou, 2013), which will especially be the case regarding intrafamily agency conflicts, a family firm may consider the need for an (high quality) auditor to be lower when already having an effective monitoring board of directors that is able to mitigate these agency conflicts or at least the negative consequences of these conflicts (i.e. the agency costs) internally.

Using questionnaire data of Belgian private family firms, we are able to grasp both the emotion-based intrafamily agency conflicts and the board's monitoring effectiveness without having to rely on compositional measures that are not able to fully take into account the heterogeneity and behaviors of/in private family firms. More specifically, we rely on family cohesion as a (negative) indicator for the intrafamily agency conflicts as it is defined as "...the emotional bonding that family members have towards one another" (Olson, 2000, p. 145) and is considered to be negatively associated with the extent to which interests among family members diverge (Olson, 2000) and thus the level of intrafamily agency conflicts. We thereby only focus on the agency conflicts that are the result of diverging interests among family members. In line with Chrisman, Chua, and Litz (2004), we do not consider the pursuit of non-economic goals at the expense of firm value to be intrafamily agency conflicts if the family members have consensus regarding these goals. In order to measure the monitoring effectiveness of the board, we rely on the board effectiveness scale of Minichilli et al. (2009) instead of the frequently used compositional measures that proxy independence as recent studies (Bammens et al., 2010; Zona, 2015) argue that board performance cannot simply be inferred from such measures. In line with most other audit demand studies that examine a 
similar context (e.g. DeFond, 1992; Francis \& Wilson, 1988; Niskanen, Karjalainen, \& Niskanen, 2011; Piot, 2001), we focus on audit quality demand instead of voluntary audit demand since the criteria to be legally required to hire an auditor are rather low in Belgium and voluntary audit demand is therefore rare. More specifically, firms with little or no need for auditing are expected to engage a cheaper non-Big4 auditor in order to fulfill the legal requirement in the most cost-effective way while the more expensive Big4 auditors will be mainly demanded by firms who have a higher actual (economic) need for auditing (Willekens \& Achmadi, 2003).

Our results confirm that the level of intrafamily agency conflicts is also a determinant of audit demand, although this demand effect is weaker when having an effective board of directors that is able to reduce the related agency costs internally. These findings add significantly to the knowledge we have about the role of auditing in private family firms in three ways. First, while this role was long considered to be minimal, recent studies show that auditing might be valuable for private family firms but only limited this value to reducing agency conflicts between family and non-family members. The present study indicates that an external audit should also be considered as an important mechanism to reduce the level or at least the negative consequences of the intrafamily agency conflicts. Second, as intrafamily agency conflicts are mainly based on emotions instead of rational behavior, we identify these agency conflicts by measuring the extent of family cohesion and in this way answer the call of Kellermanns et al. (2014) to integrate concepts of other fields in the family firm literature to advance our understanding about how emotions may influence strategic decisions. Third, this study sheds light on the role of the board of directors within the audit demand curve in this specific context, by which we contribute to the limited knowledge we have about how the several monitoring mechanisms may influence each other, especially regarding the mitigation of intrafamily agency conflicts. 
The remainder of this article proceeds as follows. In the next section, we give a brief overview of past audit demand literature, after which we develop testable hypotheses related to the influence of intrafamily agency conflicts and the monitoring effectiveness of the board on audit demand in private family firms. Section 3 describes our data and methodology. Our results are presented in section 4 and our conclusions can be found in section 5 .

\section{Theory and hypotheses}

\subsection{Audit demand in private family firms}

A considerable amount of literature has been published on audit demand, which includes both the voluntary demand for an auditor (e.g. Carey et al., 2000; Chow, 1982; Niemi et al., 2012) and the demand for audit quality (e.g. DeFond, 1992; Francis \& Wilson, 1988; Niskanen et al., 2011; Piot, 2001). Voluntary audit demand studies focus on firms that are not required by law to have their financial statements audited (e.g. private firms in the USA) and therefore examine the drivers for the voluntary appointment of an auditor. Audit quality demand studies focus on firms that are already required by law to hire an external auditor (e.g. listed companies, larger private companies in European countries, etc.) and therefore examine the drivers for hiring a high quality auditor. Although the present study actually relates to the second group of audit quality demand studies, both voluntary audit demand and audit quality demand are based on the same theoretical framework.

More specifically, audit demand studies generally rely on agency theory to explain the demand for voluntary or high quality auditing. Agency theory considers both the owners and managers of a company to be utility maximizers. In order to maximize their own utility, managers (the agents) will not always act in the best interest of the owners (the principals), which leads to agency costs (Jensen \& Meckling, 1976). Principals will try to limit 
divergences from their interest by monitoring and contracting (e.g. management compensation contracts based on performance) (Jensen \& Meckling, 1976; Lennox, 2005). These activities, however, often rely on the accounting numbers. Since these are generally prepared by management, there is information asymmetry between the managers and the owners and the latter are therefore limited in their ability to effectively monitor and contract with managers (Chow, 1982; Lennox, 2005). By verifying the validity of the financial statements, auditing reduces these existing information asymmetries and therefore contributes to the reduction of agency $\operatorname{costs}^{1}$ (Becker et al., 1998). Audit demand literature therefore generally hypothesizes a positive association between the level of shareholder-manager ${ }^{2}$ agency conflicts (generally measured by the number of owners or the level of management ownership) and audit demand. The results of several studies also support this hypothesis within both a listed (e.g. DeFond, 1992; Firth \& Smith, 1992) and private firm (e.g. Hope, Langli, \& Thomas, 2012; Niskanen et al., 2011) context.

Within a context of private family firms, however, audit demand remains a relatively unexplored research area (Songini, Gnan, \& Malmi, 2013). This is probably due to the fact that agency theory expects only a limited level of agency conflicts in such firms. Most managers are also owners of the firm and will therefore behave more like owners as well. Moreover, family bonds will facilitate monitoring and disciplining each other (Fama \& Jensen, 1983a, 1983b). The higher management ownership levels and the existence of family

\footnotetext{
${ }^{1}$ Agency costs include the reduction in welfare experienced by the principals due to self-interested behavior by the manager as well as the monitoring and bonding (related to the provision of incentives) costs to mitigate this behavior (Jensen \& Meckling, 1976). Since auditing can be classified as a monitoring cost, it can therefore also be considered as an agency cost. Auditing will therefore only be demanded when the overall reduction in agency costs is higher than the cost of the audit.

${ }^{2}$ Several audit demand studies also examined the influence of the level of shareholder-debtholder agency conflicts on audit demand (e.g. Firth \& Smith, 1992; Reed et al., 2000). We do not elaborate on this type of agency conflicts and their influence on audit demand in this study.
} 
bonds are therefore considered to reduce both the incentive and the possibility to behave opportunistically. These characteristics, however, do not prevent the occurrence of potential agency conflicts between family and non-family members. Such conflicts may arise as a result of different opinions regarding the firm's goals, family employment or investment decisions (Lubatkin, Schulze, Ling, \& Dino, 2005; Schulze et al., 2001). While non-family members are generally considered to pursue economic goals, family members often consider the preservation of socioemotional wealth (SEW) to be critical, leading to decisions not driven by economic logic (Berrone, Cruz, \& Gomez-Mejia, 2012), which may induce these conflicts. The scarce amount of studies that did examine audit demand in the private family firm context (Carey et al., 2000; Collis, 2012; Collis et al., 2004; Niemi et al., 2012; Niskanen et al., 2010) therefore focused on the audit demand effect of these agency conflicts between family and non-family members. Carey et al. (2000) considered the representation of nonfamily members in the firm as an indicator of agency conflicts between family and non-family members and indeed found it to be positively associated with audit demand. Other studies consider the ownership structure as catalyst for such agency conflicts, in which the level of agency conflicts is expected to increase as family ownership decreases. Niskanen et al. (2010) linked family ownership to audit demand and found it to be negatively related to audit demand. Collis et al (2004), Niemi et al. (2012) and Collis (2012) controlled for complete (100\%) family ownership while examining private firms and found that completely familyowned private firms demand less auditing, supporting the thesis that the presence of nonfamily owners leads to more audit demand due to a higher level of agency conflicts between family and non-family members.

While valuable, these studies do not take into account that (agency) conflicts can also arise within the family. We therefore want to add to these studies by examining whether audit 
demand is also driven by the level of agency conflicts among family members, being the level of intrafamily agency conflicts.

\subsection{Intrafamily agency conflicts}

Although some family firm studies support the traditional view of agency theory that agency conflicts among family members are minimal (Ang, Cole, \& Lin, 2000; Chrisman et al., 2004; Daily \& Dollinger, 1992), other family firm studies (e.g. Burkart, Panunzi, \& Shleifer, 2003; Chrisman, Chua, Kellermanns, \& Chang, 2007; Gomez-Mejia et al., 2001; Schulze, Lubatkin, \& Dino, 2003b; Schulze et al., 2001) argue that the agency theory may be too optimistic about family relationships in private family firms. They argue that agency conflicts among family members will arise as well because relationships in such firms are often based on emotions and sentiments instead of economically rational behavior as suggested by traditional agency theory (Gomez-Mejia et al., 2001).

These emotions can both improve and deteriorate the relationships among family members and can therefore have both a positive and negative effect on the level of intrafamily agency conflicts. Schulze et al. (2003a, 2003b; 2001), for example, refer to altruism as driver of these emotion-based agency conflicts. Among family members, a high level of altruism is generally considered to lead to a convergence of interests since it compels the ownermanagers to take into account the needs of all family members when making decisions (Schulze et al., 2003a) and is therefore associated with a low level of intrafamily agency conflicts (Karra, Tracey, \& Phillips, 2006; Kellermanns \& Eddleston, 2004, 2007). However, when altruism decreases or becomes asymmetric, which often arises in family firms since parents are generally considered to care more for their children than children do for either their parents or each other (Chakrabarti et al., 1993; Stark, 1989; Stark \& Falk, 1998; in: 
Lubatkin et al., 2005), intrafamily agency conflicts will arise. Lambrecht and Lievens (2008) refer, among others, to family complexity, which is generally defined by the number of family members, the kind of relationships among them and the number of generations involved. They consider this family complexity as a determinant for the intrafamily agency conflicts since more family complexity leads to less commitment, more differences regarding personal goals and a dilution of their relationships with each other (Gimeno Sandig et al., 2006; Montemerlo, 2005; Ward, 1997; in: Lambrecht \& Lievens, 2008). Other causes of intrafamily agency conflicts are the offspring's desire for autonomy, emotional conflicts between parents or sibling rivalry (Nicholson, 2008a, 2008b). Finally, as indicated by Sharma et al. (2001), dissatisfaction about the role in the family firm may also induce intrafamily agency conflicts since it may hinder family members in working harmoniously together and may therefore engender opportunistic behavior. When the firm inappropriately copes with the intrafamily agency conflicts, family members may start free riding, consuming perks and shirking, even if this harms other family members and/or the firm (Karra et al., 2006).

Therefore, when intrafamily agency conflicts arise in family firms, there may also be a demand for an (high quality) auditor to reduce the related agency costs (i.e. the negative consequences of the conflicts) since an examination of the accounting figures will discourage family members to behave opportunistically. Being able to reduce the existing information asymmetries between the family members (which are more likely to arise when the level of intrafamily agency conflicts is high), an auditor could also be demanded to 'de-emotionalize' the discussions within a family firm and to help its members in making more rational decisions again. Moreover, auditors may also be able to facilitate the family problems itself (Jaffe, Lane, Dashew, \& Bork, 1997) by performing a mediating role, in which he/she can offer a view that is independent from emotion, interest and ambition (Collin, Ahlberg, Berg, Broberg, \& Karlsson, 2015). 


\subsection{Cohesion as indicator for the level of intrafamily agency conflicts}

Cohesion, also labeled as 'togetherness', is an established concept in the group effectiveness literature (Klein \& Mulvey, 1995). More specifically, it is considered as “...the tendency for a group to stick together and remain united in the pursuit of its ... objectives" (Tekleab, Quigley, \& Tesluk, 2009, p. 174). Highly cohesive groups are therefore expected to actively contribute toward common goals (Tajfel \& Turner, 1986; in: Andrews, Kacmar, Blakely, \& Bucklew, 2008).

Michael-Tsabari and Lavee (2012) already theoretically coupled the family cohesion literature with the family firm literature and highlighted the value of integrating cohesion in this research stream since it gives a better understanding of the family itself, which is often neglected but highly necessary to get a better overall understanding of the behavior and decision making in family firms (Chua et al. 2003, Dyer 2003, in: Michael-Tsabari \& Lavee, 2012). Regarding our research purposes, family cohesion is able to actually grasp the emotional aspect of the intrafamily agency conflicts and in this way we are able to provide a more complete view about audit (quality) decision making in family firms.

While management ownership measures the economic bonding that managers have towards the owners (the more shares the managers own, the more they will behave in line with the owners' interests) according to agency theory (Fama \& Jensen, 1983a, 1983b; Jensen \& Meckling, 1976), family cohesion can be described as “...the emotional bonding that family members have towards one another" (Olson, 2000, p. 145). More specifically, family cohesion is considered to be negatively associated with the extent to which interests among family members diverge (Olson, 2000).

Just like management ownership is a negative indicator for the level of the rational shareholder-manager agency conflicts, family cohesion can be considered as a negative 
indicator for the level of the emotional intrafamily agency conflicts. Comparable to the zero agency situation as defined by Jensen and Meckling (1976), in which management owns $100 \%$ of the firm's shares, Olson (2000) defines a situation (the enmeshed family) in which the cohesion levels are so high that there is almost complete consensus within the family and an extreme amount of emotional closeness. Such a situation can therefore be considered as the zero agency situation regarding the intrafamily agency conflicts, especially when following the definition of Chrisman et al. (2004) that “...agency costs arise only when firm actions contravene owners' interests or when resources must be expanded to ensure that firm actions do not contravene owners' interests" (p. 336). While a high level of cohesion may, for example, also lead to the commonly mentioned (agency) behavior of hiring unqualified family members at the expense of firm value (e.g. Lubatkin et al., 2005), highly cohesive families are expected to have complete consensus regarding the goal of family employment and such behavior will therefore not be considered to be an intrafamily agency conflict. This is completely in line with Chrisman et al. (2004), who state that "[i]f a family decides that providing jobs for its less able members is in its interest and management does provide the jobs, there is consumption of perks, which would be an agency cost in a non-family firm, but not in a family firm" (p. 338). Such behavior could of course still be considered to be an agency conflict between family and non-family members, but examining the influence of this type of agency conflict on audit demand is not the focus of this study (although we do control for this type of agency conflicts in our empirical analysis).

While a high level of cohesion can therefore be associated with a low level of intrafamily agency conflicts, this level of agency conflicts starts to increase when the level of cohesion decreases. The lower the level of family cohesion becomes, the more the family members are expected to behave individualistically and the more limited their attachment and commitment to their family is (Olson, 2000). This argument can be expanded towards 
commitment to the firm as well since the results of Lansberg and Astrachan (1994) indicate that family cohesion is positively associated with the family's commitment to the firm. In families with a very low level of cohesion (the disengaged family), "[t]here is little involvement among family members and there is a great deal of personal separateness and independence" (Olson, 2000, p. 147), leading to families in which the individual interests of the family members predominate and in which they are unable to turn to each other for support and problem solving (Olson, 2000).

Regarding audit demand, we hypothesize a negative association between the level of family cohesion and audit demand. Ceteris paribus, we do not expect a demand for an (high quality) auditor when the level of family cohesion is high (i.e. a low level of intrafamily agency conflicts). Not only will the interests among the family members be generally aligned, they will also turn to each other when a dispute should occur because of their close emotional bonding, and there is therefore no need for an independent third party to solve the (consequences of the) dispute.

When the level of family cohesion declines, however, an (high quality) auditor may become interesting for private family firms to reduce the level of intrafamily agency conflicts or the related agency costs. Because diverging interests will arise, there is a higher probability that family members will engage in opportunistic behavior and that they will be unwilling to turn to each other to solve the existing problems. Therefore, as mentioned in the previous section, they may engage an (high quality) auditor to discourage potential opportunistic behavior by family members and/or to mediate the relationship among them. Formally, we therefore posit:

H1: The level of family cohesion is negatively associated with audit demand. 


\subsection{The moderating role of the board of directors}

Since the board of directors has a prominent role in auditor selection (Beasley \& Petroni, 2001; Carcello, Hermanson, Neal, \& Riley Jr, 2002), it may also influence the relationship between the level of intrafamily agency conflicts and audit demand. More specifically, a board of directors will evaluate the level of agency conflicts and will stimulate the demand of an (high quality) auditor when this is a cost-effective way to reduce the related agency costs. The board will therefore not stimulate and even hold up the engagement of an (high quality) auditor in case of a minimal level of agency conflicts or if there are alternatives to mitigate the level of agency conflicts, since the cost related to this audit (including the audit fee, the time investment, etc.) would be higher than the reduction in agency costs.

The monitoring effectiveness of the board could possibly be considered as such an alternative. More specifically, being the main representative of the shareholders, one of the main roles of the board of directors is monitoring and controlling management in order to reduce agency costs (Eisenhardt, 1989; Fama \& Jensen, 1983b; Zahra \& Pearce, 1989). In order to effectively fulfil this role, the board should monitor the firm's performance, assess strategic decisions, supervise the CEO, develop plans and budgets, etc. (e.g. Johnson, Daily, \& Ellstrand, 1996; Minichilli et al., 2009; Zahra \& Pearce, 1989). In a family firm context, however, the monitoring role also encompasses the mitigation of agency conflicts among family members (Voordeckers, Van Gils, \& Van den Heuvel, 2007). It is argued that “...boards of directors should focus on reducing information asymmetries between the various family units and monitoring managerial behavior" to reduce the related intrafamily agency costs (Bammens et al., 2008; Bammens \& Voordeckers, 2009; Steier, 2001; in: Bammens et al., 2010, p. 4). However, because of their overlapping goals, an audit could also contribute to the monitoring effectiveness of the board by providing objective financial data since information asymmetries towards the board may also arise. 
Dependent on whether the board and an auditor are considered as alternatives (i.e. substitutes) or rather as complements to mitigate intrafamily agency costs, an effective monitoring board could both positively and negatively influence the relationship between the level of agency conflicts and audit demand.

Regarding the traditional agency conflicts between owners and managers in nonfamily firms, most authors consider the board and the auditor as complements, indicating that an effective board further increases the demand for an (high quality) audit in order to be better able to monitor management (e.g. Beasley \& Petroni, 2001; Carcello et al., 2002; Carcello, Hermanson, \& Ye, 2011; Chen \& Jian, 2007).

Regarding the mitigation of intrafamily agency costs in a family firm context, however, a substitution effect may be much more likely to prevail. Since privacy and confidentiality are considered to be two of the most important values for family firms (Lester \& Cannella, 2006; Su \& Dou, 2013), a family firm may be reluctant to hire an (high quality) external auditor, especially to mitigate and thus exposing family relationships. They may therefore rather try to mitigate the intrafamily agency conflicts internally first, through the board of directors, and only consider an (high quality) external audit as an alternative when the board fails.

This view is in line with the socioemotional wealth (SEW) perspective, stating that “...family firms are likely to place a high priority on maintaining family control even if this means accepting an increased risk of poor firm performance" (Gómez-Mejía, Haynes, NúñezNickel, Jacobson, \& Moyano-Fuentes, 2007, p. 106). Since involvement of outsiders may be perceived as a loss of family control (Jones, Makri, \& Gomez-Mejia, 2008), private family firms may initially be reluctant to hire an (high quality) auditor to preserve their SEW, even if this could rationally be considered as a good investment complementary to the board to be 
better able to reduce the intrafamily agency costs and therefore increase firm performance. However, although SEW preservation may be the primary goal in family firms, it is argued that the family may be forced to reconsider this in case of severe poor performance (or in our case: severe intrafamily conflicts that the board is not able to mitigate) because firm failure would lead to a complete SEW extinction (Berrone et al., 2012), which means that family firms may eventually hire (high quality) outsiders to increase firm performance (or in our case: decrease the intrafamily agency costs) again.

We therefore argue that a kind of order exists regarding to how a family firm tries to mitigate intrafamily agency conflicts (if present). First, the family members will try to monitor the behavior of the family managers internally by the board of directors. When the board's monitoring effectiveness is low, however, the board will not be able to reduce the related agency costs and in that situation the family may consider to hire an (high quality) external auditor. We therefore hypothesize that the monitoring effectiveness of the board moderates the association between the level of intrafamily agency conflicts and audit demand in such a way that the association is weaker when having a high monitoring effectiveness of the board. Put formally and including our measure for the level of intrafamily agency conflicts, we thus posit:

H2: The monitoring effectiveness of the board moderates the negative association between the level of family cohesion and audit demand in such a way that the association is weaker when having a high monitoring effectiveness of the board. 


\section{Data and methodology}

\subsection{Data}

We use data of Belgian private family firms to test our hypotheses. Since the thresholds to be legally required to hire an auditor are rather low in Belgium, voluntary audit demand is rare in the Belgian private firm context. More specifically, a Belgian firm is required to hire an auditor when the annual average workforce is higher than 100 or when at least two of the following thresholds are exceeded: annual average workforce of 50 employees, balance sheet total of 3650000 EUR and turnover of 7300000 EUR (article 15 of the Belgian Company Legislation). In line with several other audit demand studies (e.g. DeFond, 1992; Francis \& Wilson, 1988; Niskanen et al., 2011; Piot, 2001), we therefore do not examine voluntary audit demand but audit quality demand.

To examine the influence of family cohesion on audit quality demand and the moderating role of the monitoring effectiveness of the board, we identified all active Belgian private firms that were legally required to be audited and are not part of the financial services industry from the Bel-First database of Bureau Van Dijk, which is in line with other audit quality demand studies (e.g. Hope et al., 2012; Niskanen et al., 2010). Unfortunately, this selection of firms still contains both family and non-family firms since no complete register of Belgian family firms exists and therefore our overall population is unknown, which is often the case in family firm studies (Collin \& Ahlberg, 2012).

To all of the selected firms, except those with insufficient contact details, we sent a structured online questionnaire in February 2015 and asked the CEO to complete it $(\mathrm{N}=$ 8662). We obtained a response from 740 firms, which equals a response rate of $8.5 \%$. We combined the data from the questionnaire with publicly available accounting data from the Bel-First database and from the individual financial statements of our sample firms. As our 
dependent variable was collected directly from the sample firms' financial statements while the explanatory variables were collected by the questionnaire, there is no common method bias threat.

In order to obtain a dataset of private family firms only, we selected those firms in which a single family owns more than 50 percent of its shares and/or in which the CEO perceives the firm as a family firm (Dyer, 2003; Westhead \& Cowling, 1998), leading to a sample of 390 firms. Moreover, since Olson's (2000) family cohesion scale is a self-report instrument and we want to focus on the influence of the intrafamily agency conflicts on audit quality demand, we only selected the firms with a family CEO $(n=231)$. After removing cases with incomplete and/or inconsistent data regarding our explanatory and control variables, we obtained a final sample of 125 firms to test our hypotheses. We performed ttests between early and late respondents regarding our explanatory and continuous control variables to check for potential response bias using cut-off points at 10, 20 and 30 percent but found no significant differences. Moreover, in order to alleviate potential outlier problems, all continuous variables were winsorized at the $1^{\text {st }}$ and $99^{\text {th }}$ percentiles.

\subsection{Variables}

\subsubsection{Dependent variable}

In line with most audit demand studies (e.g. Fan \& Wong, 2005; Firth \& Smith, 1992; Lennox, 2005; Piot, 2001), our dependent variable, audit quality, is proxied by a dummy variable BIG4 which is coded 1 if the firm hired a Big4 auditor and 0 otherwise. This proxy is based on DeAngelo (1981), who states that larger audit firms have more to lose in case of an audit failure and will therefore provide a higher level of audit quality. Several studies also support this thesis (e.g. Becker et al., 1998; Francis, Maydew, \& Sparks, 1999) although there are also a number of studies that did not find a significant difference in audit quality between 
$\mathrm{BigN}^{3}$ and non-BigN audit firms (e.g. Boone, Khurana, \& Raman, 2010; Lawrence, MinuttiMeza, \& Zhang, 2011). However, not the actual level of audit quality is important to examine audit demand but rather the perceived level of audit quality. Boone et al. (2010) and Karjalainen (2011) found that Big4 audit firms are still perceived to provide higher levels of audit quality and therefore the BIG4 dummy remains a valuable proxy to measure audit quality demand.

More specifically, firms with little or no need for auditing are expected to engage a cheaper non-Big4 auditor in order to fulfill the legal requirement in the most cost-effective way while the more expensive Big4 auditors will be mainly demanded by firms who have a higher actual (economic) need for auditing (Willekens \& Achmadi, 2003). Although the cost of a Big4 auditor is often considered as a reason not to hire such an auditor, this also reflects that the firm faces a lower need for auditing (i.e. a lower level of agency conflicts). In case there is a high need for auditing, firms will fulfill this need by hiring an auditor that is considered to provide a high level of audit quality, i.e. the Big4 auditors (Boone et al., 2010; Karjalainen, 2011), even though they are more expensive.

\subsubsection{Explanatory variables}

In order to test our hypotheses, we use Olson's (2000) family COHESION scale, which is part of the FACES IV package. Despite the self-report nature of this instrument, it is “...one of the few statistically reliable and valid measures of family behavior available" (Green et al. 1985, Olson 1986, Olson et al. 1988, in: Lansberg \& Astrachan, 1994, p. 49). This measure is therefore largely used in studies focusing on family relations and dynamics, types of families, family counseling and education, etc. (Kouneski, 2000). Using a 5-point Likert scale,

\footnotetext{
${ }^{3}$ Due to the disappearance of Arthur Andersen and due to mergers between audit firms, the audit quality measure gradually evolved from Big8 to Big4.
} 
respondents were asked to give their opinion about 21 items, including for example "Family members consult other family members on important decisions", "Family members are involved in each others lives" and "We get along better with people outside our family than inside" (negative item) (Olson, 2010, pp. 5-6). These 21 items can be divided into 3 groups of 7 items labeled balanced (which measures to what extent the level of cohesion is moderately high/low), enmeshed (which measures to what extent the level of cohesion is very high) and disengaged (which measures to what extent the level of cohesion is very low) (Olson, 2000). The negative items relate to the disengaged group and an overall cohesion score can therefore be calculated as follows: balanced score + enmeshed score - disengaged score. The Cronbach alpha for this 21 -item scale is found to be 0.85 .

While the effectiveness of the board of directors is generally proxied by compositional measures like board size, the percentage of outside directors, director shareholdings, CEO duality or the financial expertise of the board members (e.g. Beasley \& Petroni, 2001; Chen \& Jian, 2007; Ireland \& Lennox, 2002), recent board literature (e.g. Finkelstein \& Mooney, 2003; Gabrielsson \& Winlund, 2000; Minichilli, Zattoni, Nielsen, \& Huse, 2012; Minichilli et al., 2009; Zona \& Zattoni, 2007) argues that composition does not necessarily explain behavior such that these proxies do not adequately measure board effectiveness. According to Zona (2015) and Bammens et al. (2010), this also applies to measuring board effectiveness in a family firm context as "great inferential leaps are made from input variables such as board composition to output variables such as board performance with no direct evidence on the processes and mechanisms which presumably link the inputs to the outputs" (Pettigrew, 1992, in: Zona, 2015, p. 105). In this study, we will therefore not rely on compositional measures for our moderating variable but use a direct measurement of the monitoring effectiveness of the board. More specifically, we rely on the measure of Minichilli et al. (2009) to proxy this monitoring effectiveness of the board. We include the 7-item measure MONITORING, in 
which all control tasks of the board are evaluated on a 5-point Likert scale, including for example "The board is actively involved in supervising the CEO" and "The board actively monitors and evaluates strategic decisions” (Minichilli et al., 2009, p. 71).

The monitoring role of the board is considered to consist of three sub-roles, namely behavioral control, output control and strategic control (Huse, 2005; Minichilli et al., 2009). The behavioral control role encompasses supervising the CEO and monitoring the top managers' behavior, the output control role mainly consists of monitoring the financial performance of the firm and the strategic control role mainly focuses on high-level strategic decision making (e.g. acquiring a new firm) (Minichilli et al., 2009). We will also include these sub-roles separately in additional models by the variables BEHAVIORAL_CONTROL, OUTPUT_CONTROL and STRATEGIC_CONTROL to get a more detailed view about the moderating influence of the monitoring role of the board on audit (quality) demand.

Even though the FACES questionnaire, including the cohesion scale, is already extensively tested (Lansberg \& Astrachan, 1994; Olson, 2011) and the scale on the board's monitoring effectiveness of Minichilli et al. (2009) is widely accepted in the governance literature, we conducted a confirmatory factor analysis to validate the scales. We allowed the error terms of the indicators to correlate but only if the terms belonged to the same construct and had a modification index score larger than the recommended level of 5 (Davis, Dibrell, Craig, \& Green, 2013) and found the results to be satisfactory for being used in our regression analysis $(\mathrm{RMSEA}=0.049 ; \mathrm{SRMR}=0.073)(\mathrm{Hu} \&$ Bentler, 1999).

\subsubsection{Control variables}

In line with Carey et al. (2000), we include NONFAMILY_MANAGERS, defined as the proportion of non-family (owner-)managers in the management team, to control for the agency conflicts between family and non-family members. Non-family (owner-)managers are 
generally considered to be more economically oriented while family members will also value non-economic goals (e.g. family employment) and this may lead to agency conflicts. We also include the natural logarithm of the number of shareholders (OWNERS) to control for the traditional shareholder-manager agency conflicts ${ }^{4}$, in which the level of agency conflicts is considered to increase with the number of owners as Grossman and Hart (1980, in: Niskanen et al., 2010) claim that "...the free rider problem among shareholders in monitoring management increases with ownership dispersion" (p. 234). LEVERAGE, defined as total debt to total assets, is included to proxy for the agency conflicts between shareholders and debtholders (Niskanen et al., 2010). Other control variables that we include are SIZE, ROA, GROUP and INDUSTRY. SIZE, defined as the natural logarithm of total assets, is included to control for the complexity of firms as more complex firms may demand more monitoring to compensate for the loss of control (Abdel-Khalik, 1989) and ROA, defined as the ratio of annual net income to total assets, is included to control for the possible effect of profitability (Niskanen et al., 2010). In line with Niskanen et al. (2010) as well, we also include GROUP, coded 1 if the firm belongs to a group and 0 otherwise. In this way, we control for both the fact that subsidiaries often have to hire the same auditor as the parent company and for the fact that parent companies themselves are also limited in their auditor choice since small auditors will not always be able to audit companies of a geographically dispersed group. Belonging to a group, both as subsidiary and as parent, is therefore considered to increase the likelihood of hiring a Big4 auditor. Finally, we also control for industry effects by INDUSTRY, coded 1 if the firm is part of the manufacturing or construction industry and 0 otherwise.

\footnotetext{
${ }^{4}$ We use this measure instead of management ownership to be consistent with Niskanen et al. (2010) since they examine the same context as we do. In our additional analyses, we also run our regressions with management ownership as proxy for the level of shareholder-manager agency conflicts but the results are similar.
} 


\subsection{Model}

In order to test our hypotheses, we employ multivariate logit regression analyses, which is in line with prior audit demand studies (e.g. Firth \& Smith, 1992; Lennox, 2005; Niskanen et al., 2010; Piot, 2001). While both logit and probit are used in the literature, we prefer logit as both methods are equally efficient but logit does not require normality of parameter distribution (Piot, 2001). More specifically, the model we use to test hypothesis 1 is specified as follows:

$$
\operatorname{Prob}(\mathrm{BIG} 4)=\frac{1}{1+\mathrm{e}^{-\mathrm{Z}}}
$$

where $Z=\beta_{0}+\beta_{1}$ COHESION $+\beta_{2}$ NONFAMILY_MANAGERS $+\beta_{3}$ OWNERS +

$$
\beta_{4} \text { LEVERAGE }+\beta_{5} \mathrm{SIZE}+\beta_{6} \mathrm{ROA}+\beta_{7} \mathrm{GROUP}+\beta_{8} \mathrm{INDUSTRY}+\varepsilon
$$

In order to test hypothesis 2, we specify the model as follows:

$$
\operatorname{Prob}(\mathrm{BIG} 4)=\frac{1}{1+\mathrm{e}^{-\mathrm{Z}}}
$$

where $Z=\beta_{0}+\beta_{1}$ COHESION $+\beta_{2}$ MONITORING $+\beta_{3}$ COHESION*MONITORING + $\beta_{4}$ NONFAMILY_MANAGERS $+\beta_{5}$ OWNERS $+\beta_{6}$ LEVERAGE $+\beta_{7}$ SIZE + $\beta_{8} \mathrm{ROA}+\beta_{9}$ GROUP $+\beta_{10 \mathrm{INDUSTRY}}+\varepsilon$

\section{Results}

\subsection{Descriptive statistics and correlations}

Our sample consists of a wide range of family firms, in which family ownership ranges from 20 to $100 \%$ (going from 1 to 25 owners). The average value of family ownership is found to be $88 \%$, indicating that the family members remain to be the largest owners in most of our sample firms. Moreover, 41 of the family firms within our sample (33 percent) are part of a group, including family firms that are subsidiaries of a larger family business group and/or 
management holding (14 firms), family firms that are subsidiaries of a non-family group (7 firms) and family firms that are parent companies of a group (20 firms).

Detailed descriptive statistics of our sample are presented in table 1. A Big4 auditor is only hired by 8 percent of our sample firms, which seems low but is not exceptional for a private family firm context as Niskanen et al. (2010) found this percentage to be around $13 \%$ while having a less strict definition of private family firms. The average value of monitoring effectiveness of the board is 13.7, its minimum is 0 and its maximum is 28 (which corresponds to the theoretical minimum and maximum as well). The average value of family cohesion is found to be approximately 24.8 while the theoretical minimum value of the scale is -21 and maximum value is 63 . Moreover, the standard deviation of family cohesion shows that there is much variation among the responses. Even though one might expect that family CEOs are less eager to honestly report on this sensitive issue of family cohesion, these data suggest that the level of social desirability is limited.

This table also compares the means or proportions of each variable between the firms that hired a BIG4 auditor and those that did not. The mean of COHESION is significantly smaller for firms that hired a BIG4 auditor, which is in line with our first hypothesis. The mean of OUTPUT_CONTROL is found to be significantly smaller for these firms as well while the mean of SIZE and NONFAMILY_MANAGERS was found to be significantly larger for firms that hired a BIG4 auditor. No other significant differences in means were found regarding the other explanatory and control variables.

Insert table 1 about here 
The correlations (both Pearson and Spearman) can be found in table 2. The correlations between COHESION and the other variables never exceed the value of 0.20 and also among the control variables the correlations remain rather low. While the correlations between the monitoring role of the board (MONITORING) and its sub-roles (STRATEGIC_CONTROL, OUTPUT_CONTROL and BEHAVIORAL_CONTROL) are higher than 0.5, which could be considered as problematic, these variables are never simultaneously included in a regression model. Moreover, the variance inflation factors (not reported) indicate no multicollinearity problem either since all values are below the critical value 10 (the highest value is 3.63 ).

Insert table 2 about here

In line with our first hypothesis, the level of COHESION is found to be negatively correlated with hiring a BIG4 auditor but only at the $10 \%$ significance level. The correlation between the monitoring effectiveness of the board (MONITORING) and hiring a BIG4 auditor is not found to be significant. With respect to the control variables, only the proportion of nonfamily managers in the management team (NONFAMILY_MANAGERS) and SIZE are significantly positively correlated with audit (quality) demand. There is no significant correlation between COHESION, measuring the extent of intrafamily agency costs, and SIZE, indicating that intrafamily agency conflicts seem to arise in both small and large firms. In addition, the correlation between COHESION and the number of owners (OWNERS) is not significant either. This gives a first indication of the value of COHESION as measure for these agency conflicts as they seem difficult to grasp by compositional measures. 


\subsection{Hypotheses tests}

Table 3 presents our logistic regression models. The table presents the beta coefficients of all explanatory and control variables, the robust standard errors, the Log likelihood statistic, the Chi-square statistic and the McFadden $\mathrm{R}^{2}$. All models are found to be significant $(\mathrm{p} \leq 0.01)$ and the $\mathrm{R}^{2}$ values range from 41 to 52 percent.

Hypothesis 1 is supported by our data since model 1 shows a significant negative coefficient for the variable COHESION $(p=0.001)$. This result therefore indicates that auditors are also demanded to mitigate the intrafamily agency costs in private family firms.

We examine the moderating effect in model 2, which supports our second hypothesis. We find a significant negative direct effect of COHESION $(p=0.005)$ again and find a significant positive coefficient for the moderating variable COHESION*MONITORING $(\mathrm{p}=$ 0.045), indicating that the monitoring effectiveness of the board moderates the association between the level of intrafamily agency conflicts and audit quality demand in such a way that the association is weaker when having a higher monitoring effectiveness of the board. Moreover, this also supports our idea that a kind of order exists regarding to how a family firm tries to mitigate intrafamily agency conflicts such that the family members will first try to monitor the behavior of the family managers internally by the board of directors, and only consider to hire an (high quality) external auditor when the board fails in doing this (i.e. when the monitoring effectiveness is low).

Insert table 3 about here 
This interpretation is further confirmed by figure 1, which graphically represents the marginal effect of COHESION on BIG4 when the MONITORING effectiveness of the board changes. This type of graph, which is regularly used when examining interaction effects (e.g. Schepers, Voordeckers, Steijvers, \& Laveren, 2014; Steijvers \& Niskanen, 2014; Vandekerkhof, Steijvers, Hendriks, \& Voordeckers, 2015), allows us to correctly interpret the interaction effect to more detail (Brambor, Clark, \& Golder, 2006; Franzese \& Kam, 2009). The marginal effects are illustrated by the solid line and are calculated by using the following equation: $\frac{\partial \text { BIG4 }}{\partial \text { COHESION }}=\beta_{1}+\beta_{3}$ MONITORING (Brambor et al., 2006). The dotted lines represent the 95\% confidence interval and the negative effect of COHESION on BIG4 is therefore considered to be significant when both the upper and lower bounds of the confidence interval are below the zero line. In line with our main results and hypothesis 1 , the graph shows that COHESION has a significant negative effect on audit demand as long as the board's monitoring effectiveness is low (below the median value of 14). In line with hypothesis 2 , this negative effect is found to weaken (the slope is positive) when the board's monitoring effectiveness increases. When having a high monitoring effectiveness (above the median value of 14), the effect of COHESION turns insignificant, further supporting our expectation that firms only demand (high quality) auditors when the firm is not able to solve the intrafamily agency conflicts internally by the board of directors.

Insert figure 1 about here

In model 3, 4 and 5 of table 3, we replace the variable MONITORING by STRATEGIC_CONTROL, OUTPUT_CONTROL and BEHAVIORAL_CONTROL respectively to get a more detailed view about which control tasks specifically lead to this 
moderation effect. We find no significant moderating effect when including STRATEGIC_CONTROL (model 3) but when including OUTPUT_CONTROL (model 4) and BEHAVIORAL_CONTROL (model 5), we find significant coefficients for both COHESION ( $p=0.004$ and $p=0.000$ respectively) and the moderating variables $\begin{array}{llll}\text { COHESION*OUTPUT_CONTROL } & (\mathrm{p} \quad \text { and }\end{array}$ COHESION*BEHAVIORAL_CONTROL $(\mathrm{p}=0.018)$.

The insignificant result regarding strategic control is not surprising since the strategic control role is considered to be particularly important when "critical choices must be made, such as acquiring a new firm, divesting a division or negotiating a takeover bid" (Baysinger and Butler 1985, Zahra and Pearce 1989, in: Minichilli et al., 2009, p. 58) and therefore does not directly relate to the mitigation of intrafamily agency conflicts.

The output control role and the behavioral control role, on the other hand, do relate to this. More specifically, the behavioral control role encompasses supervising the CEO and monitoring the top managers' behavior and is therefore considered to have an internal focus (Boyd, 1995, in: Minichilli et al., 2009). Direct observation of management's behavior is considered to be one of the most effective ways to reduce agency conflicts but is often difficult to achieve due to the existence of information asymmetry between the board and management (Minichilli et al., 2009). The output control role mainly consists of monitoring the financial performance of the firm (Minichilli et al., 2009), which may especially be important for private family firms since family members may have different views on performance standards (growth in earnings versus growth in valuation) and may therefore also trigger intrafamily conflicts (Schulze et al., 2003a). However, due to the existence of information asymmetries as well (the financial statements are generally prepared by management itself), the board is not always able to fulfil this role sufficiently. 
Our results therefore suggest that a firm in which the board is able to execute the behavioral control and output control role effectively will have a lower need to hire an (high quality) auditor to reduce the intrafamily agency conflicts compared to a firm in which the board is not able to perform these tasks effectively, in which an (high quality) auditor will be much more useful to assist in mitigating these intrafamily agency conflicts.

Regarding the control variables, the coefficients of SIZE, LEVERAGE and GROUP are positive and significant in all models, which is in line with most audit demand studies (e.g. Dedman, Kausar, \& Lennox, 2014; Niskanen et al., 2010, 2011; Piot, 2001). The coefficient of NONFAMILY_MANAGERS is also significantly positive in each model, supporting the audit demand effect of agency conflicts between family and non-family members as found by Niskanen et al. (2010) and Carey et al. (2000). OWNERS was not found to be significant, indicating that audit demand is to a lesser extent determined by the traditional shareholdermanager agency conflicts. Unlike the traditional idea of audit demand literature that the role of auditing would be limited in private family firms, our results show that external auditing remains to have an important role in these firms, more specifically to reduce the costs associated with the family related agency conflicts (both between family and non-family members and among family members).

\subsection{Additional tests}

We conducted several additional analyses in order to test the robustness of our findings, of which the results can be found in table $4 \mathrm{a}$ and $4 \mathrm{~b}$. These tables mainly represent results comparable to our main analyses (model 1 and 2 of table 3). The robustness tests on model 3, 4 and 5 of table 3 are not tabulated due to space considerations but are also described in the following paragraphs. 
Since we had to drop 45 cases due to missing data regarding the monitoring effectiveness of the board, we also ran model 1 without the removal of these cases, leading to a dataset of 170 firms (model 1 of table 4a). The coefficient of COHESION was found to be significant at the $1 \%$ significance level $(\mathrm{p}=0.004)$ when using this dataset as well, supporting our results regarding hypothesis 1 .

We also ran our regressions using other proxies for both our dependent and independent variables. More specifically, we replaced our dependent variable BIG4 by $\mathrm{BIG} 4 \& \mathrm{BDO}$ in our models since the predominance of the Big4 companies is not that pronounced in the Belgian context, in which BDO is also a very strong audit company (BDO is only between 17 and 31 percent smaller in terms of auditors compared to the other Big4 companies while the sixth largest audit company in Belgium is 45 percent smaller than BDO) (model $2 \mathrm{a}$ and $2 \mathrm{~b}$ of table $4 \mathrm{a}$ ). When using this dependent variable in our models (11 percent of our sample firms hired a Big4 auditor or BDO), the results remain in line with our main results. The coefficient of COHESION was found to be negative and significant in all models (the p-values range between 0.000 and 0.050 ) and the moderating variables COHESION*MONITORING $(\mathrm{p}=0.020)$, COHESION*OUTPUT_CONTROL $(\mathrm{p}=0.054)$ and COHESION*BEHAVIORAL_CONTROL $(\mathrm{p}=0.007)$ were found to be significant as well.

Insert table $4 \mathrm{a}$ about here

In model $3 \mathrm{a}$ and model $3 \mathrm{~b}$ of table $4 \mathrm{a}$, we use a slightly different calculation of the level of COHESION. More specifically, since enmeshed and disengaged are two unbalanced scales of cohesion, one could argue they should not account for $2 / 3$ of the overall cohesion score. We therefore also ran our regressions with a slightly adjusted measure (COHESION_ADJ) for 
family cohesion as suggested by Olson (2010), namely: balanced cohesion + (enmeshed disengaged)/2. The results remain completely in line with our main results. COHESION_ADJ is found to be significant and negative in all models (the p-values range between 0.000 and 0.013) and COHESION_ADJ*MONITORING $(\mathrm{p}=0.019)$, COHESION_ADJ*OUTPUT_CONTROL $\quad\left(\mathrm{p} \quad=\quad \begin{array}{lll}\text { 0.015 } & \text { and }\end{array}\right.$ COHESION_ADJ*BEHAVIORAL_CONTR $(\mathrm{p}=0.015)$ are all found to be significantly positive.

Since the generation of the owning family is often proposed as a proxy for the level of intrafamily agency conflicts in family firm studies as well (e.g. Blanco-Mazagatos et al., 2007; Schulze et al., 2003a), we also replaced COHESION in our models by GENERATION, indicating which generation currently has the majority of the shares (model $4 \mathrm{a}$ and $4 \mathrm{~b}$ of table 4a). None of its coefficients were found to be significant, however, which seems to confirm our argumentation that a compositional measure like GENERATION is not fully able to capture the heterogeneity of family firms regarding the level of intrafamily agency conflicts.

Similarly, compositional measures are also often used to proxy board effectiveness. With respect to this study, it might be argued that boards with a high percentage of family members will be weaker in mitigating intrafamily agency conflicts as they may be part of the conflict. On the other hand, boards with a high percentage of outsiders are expected to be better able to reduce (the negative consequences) of these intrafamily agency conflicts as they are less involved in the conflicts and will therefore behave more independently and less emotionally. In order to examine this, we ran a regression in which we include COHESION*FAMILY_BOARD (in which FAMILY_BOARD is a dummy coded 1 if the ratio of the number of family board members to total board size is larger than the average value of this ratio within our sample) and COHESION*NONFAMILY_BOARD (in which NONFAMILY_BOARD is defined as (1-FAMILY_BOARD)) as explanatory variables. Both 
variables have a strongly significant and negative effect (p-values of 0.002 and 0.005 respectively, see model 5 of table 4 a), indicating that intrafamily agency conflicts lead to audit demand in both firms that have a family dominated board and those that do not. Consequently, a family dominated board does not seem weaker in reducing intrafamily agency conflicts. It therefore seems to confirm the findings of recent board literature that board composition itself does not necessarily explain behavior (e.g. Finkelstein \& Mooney, 2003; Gabrielsson \& Winlund, 2000; Minichilli et al., 2012; Minichilli et al., 2009; Zona \& Zattoni, 2007) within a family firm context and in this way shows the value of the measure of Minichilli et al. (2009) that we used in this study.

In order to further examine the robustness of our findings regarding the moderating effect of the board of directors, we also used a different measure to proxy its monitoring effectiveness (MONITORING_ALT). More specifically, we use the monitoring component of the index of Westphal (1999, p. 24), which includes the items "To what extent does the board monitor top management strategic decision making?" (DECISIONMAKING_CONTROL), "To what extent does the board formally evaluate your performance?" (PERFORMANCE_CONTROL) and "To what extent does the board defer to your judgment on final strategic decisions?" (DECISION_CONTROL). The results (model 6 of table 4b) are in line with our main results since we also find a significant positive moderating effect for the monitoring role of the board when using this measure $(\mathrm{p}=0.050)$. We also included the three items of the index of Westphal (1999) separately as moderators in three additional models (model $7 \mathrm{a}, 7 \mathrm{~b}$ and $7 \mathrm{c}$ of table $4 \mathrm{~b}$ ). Only the second and third model show significant moderating effects (p-values of 0.042 and 0.046 respectively), which is in line with our main results as well because these indicators mainly focus on the role of the board in controlling CEO performance and decision making while the first indicator mainly focuses on the strategic decision making process. 
In model $8 \mathrm{a}$ and model $8 \mathrm{~b}$ of table $4 \mathrm{~b}$, we use alternative proxies for the control variables. In order for our results to be valuable, it is especially important that we are able to control for the agency conflicts between family and non-family members. Therefore, we also ran our regressions again with FAMILY_OWNERSHIP (the percentage of shares owned by the family), being an alternative measure for NONFAMILY_MANAGERS used by Niskanen et al. (2010), to control for these conflicts. The results regarding the explanatory variables remain completely in line with our main findings when using this alternative. While NONFAMILY_MANAGERS was found to be significant in all models, however, FAMILY_OWNERSHIP itself just surpasses the $10 \%$ significance threshold in these additional analyses, which may be due to the fact that it also partly grasps the traditional agency conflicts between owners and managers. We also ran our models with alternatives for the other control variables (e.g. MANAGEMENT_OWNERSHIP to measure the level of agency conflicts between owners and managers instead of OWNERS (Lennox, 2005)) and also added several other potential control variables (e.g. the QUICK ratio, the company's AGE, whether the company EXPORTs and whether the managers have a VARIABLE_REMUNERATION scheme) found in the audit demand literature (e.g. Francis \& Wilson, 1988; Lennox, 2005; Niskanen et al., 2010). When including these control variables, the results ${ }^{5}$ regarding the explanatory variables remain completely in line with our main findings as well.

Finally, in order to examine whether our main result regarding COHESION could also be explained by a size effect, we ran this model again with only the firms that have a size larger than the median size in the sample. COHESION remains strongly significant in this

\footnotetext{
${ }^{5}$ Results not reported due to space considerations but available from the authors on request.
} 
analysis but so does SIZE (model 9a of table 4b). When only including firms that have a size larger than the average size in the sample, the significance of SIZE decreased to the $10 \%$ significance threshold while the coefficient of COHESION remains strongly significant and negative like in our main analyses (model $9 \mathrm{~b}$ of table $4 \mathrm{~b}$ ). This further confirms that the main result of our study is not a size effect but actually relates to the level of intrafamily agency conflicts.

\section{Conclusions}

\subsection{Overview}

In this study, we examine whether audit (quality) demand is also driven by the level of intrafamily agency conflicts. As “...family bonds engender agency contracts that are prone to depart from economic rationality" (Gomez-Mejia et al., 2001, p. 82), we used the level of family cohesion to identify these intrafamily agency conflicts. We hypothesized that the level of family cohesion is negatively associated with audit (quality) demand, which was supported by our data.

Moreover, we also hypothesized that the monitoring effectiveness of the board of directors may weaken the association between family cohesion and audit (quality) demand since family members may, due to the importance of privacy and confidentiality, try to solve the intrafamily agency conflicts internally first, through the board of directors, and only consider an (high quality) external audit as an alternative when the board fails. This hypothesis was also supported by our data.

Since the monitoring role is considered to consist of three sub-roles, namely strategic control, output control and behavioral control (Huse, 2005; Minichilli et al., 2009), we also examined the individual effects of each sub-role separately and found a significant 
moderating effect when including output control and behavioral control but not when including strategic control. These results therefore suggest that a firm in which the board is able to execute the behavioral control role (which encompasses supervising the CEO) and output control role (which mainly consists of monitoring the financial performance of the firm) effectively will be able to reduce the intrafamily agency costs internally and will therefore have a weaker relationship between the potential level of agency conflicts and audit (quality) demand compared to a firm in which the board is not able to execute these roles effectively.

\subsection{Theoretical implications}

We believe that our findings regarding the relationship between the level of intrafamily agency conflicts and audit demand and the moderating effect of the board of directors on this relationship contribute significantly to the literature. In the first place, we contribute to the family firm literature by highlighting a topic, audit demand, that has received little attention in this literature stream (Salvato \& Moores, 2010; Songini et al., 2013). Moreover, we also add to two notable exceptions that did examine audit demand in this private family firm setting, namely the studies of Carey et al. (2000) and Niskanen et al. (2010). They found that private family firms also demand (high quality) auditing to reduce agency conflicts between the family and non-family members. We add to these studies by examining whether (high quality) auditing is also demanded to reduce agency conflicts that arise among family members (intrafamily agency conflicts).

Moreover, by using family cohesion as indicator for the level of intrafamily agency conflicts, we are also more able to take into account the heterogeneity of private family firms. While compositional measures like generational or ownership stage of the family firm are suggested and used in the literature to proxy the level of intrafamily agency conflicts, several 
drawbacks are associated with these measures. One could argue that agency conflicts will increase when generations progress and/or ownership disperses because the level of altruism may reduce (Lubatkin et al., 2005; Schulze et al., 2003a), goals are more likely to diverge (Miller \& Le Breton-Miller, 2006) and family complexity increases (Lambrecht \& Lievens, 2008). However, these arguments may not hold for all private family firms that evolve over generations and these proxies may therefore not be able to take into account the heterogeneity of private family firms, which is considered to be a very important aspect within the family firm literature (e.g. Burkart et al., 2003; Chrisman et al., 2007; Gomez-Mejia et al., 2001; Schulze et al., 2003b; Schulze et al., 2001).

By measuring emotions more directly, we also answer the call of Kellermanns et al. (2014) to integrate concepts of other fields in the family firm literature in order to advance our understanding about how emotions may influence strategic decisions. We are aware, however, that other similar concepts, such as family identity, familiness, family involvement or the items included in the Family Climate Scales (Björnberg \& Nicholson, 2007) may be suitable to measure the emotions related to the level of intrafamily agency conflicts as well and therefore we agree with Kellermanns et al. (2014) that future research needs to assess which measures and which research designs measure emotions in family firms the most successfully.

This study also contributes to the auditing and accounting literature, in which we consider the introduction of emotionally related constructs to be our main contribution. While most audit demand studies still fully rely on traditional agency theory and therefore expect the demand for auditor services to be minimal in private family firms because of the low level of agency conflicts, we depict a completely different view by focusing on the family firm literature and find that private family firms do demand (high quality) auditing to reduce family related (and emotion based) agency conflicts. By examining private family firms, we also answer the call of Trotman and Trotman (2010) to focus more on family businesses in the 
accounting literature. Moreover, we also contribute to this literature by actually measuring the monitoring effectiveness of the board of directors (instead of using compositional measures that proxy for board independence) and by examining its influence on audit demand. In this way, we also answer the call of Cohen et al. (2004) to examine the role of the entire board in auditor selection and to examine board characteristics other than independence only.

\subsection{Practical implications}

By taking a heterogeneous perspective on family firms and by revealing that family firms will demand an (high quality) auditor to mitigate intrafamily agency costs, which is the opposite of what was traditionally expected (e.g. Fama \& Jensen, 1983b), our findings may also be very interesting for auditors. Private family firms were long considered to have a minimal need for auditing and the private family firms that did engage an auditor were therefore expected to do this for other reasons than reducing agency conflicts. More specifically, an external audit only seemed to serve the purpose of complying with requirements (e.g. due to a statutory audit requirement or a requirement from financial institutions, because it is imposed by the firm's group, etc.). This study, however, shows that an external audit is also valuable for private family firms to de-emotionalize the intrafamily agency conflicts. Auditors could benefit from these findings by investing in family firm knowledge and by identifying their specific needs regarding the audit engagement in order to conform their services more to these needs and in this way create more value for both themselves and their clients.

A second finding that deserves the attention of practitioners relates to the moderating effect of the board of directors. More specifically, the results of this study indicate that family firms will consider the need for an (high quality) auditor to be lower when already having an effective monitoring board. Directors and family firm members (e.g. family shareholders, 
family managers, family employees, etc.) should question whether they should indeed consider the role of the board and the auditor as alternatives regarding the reduction of intrafamily agency conflicts. Intuitively, an effective monitoring board could still benefit from the information of an external audit as this information could be considered to be free of personal interpretations, emotions, etc. This could assist the board of directors in negotiating and discussing with family members in order to reduce potential intrafamily agency conflicts. Dividend negotiations, for example, could be much easier when everyone is convinced about the trustworthiness of the financial statements and therefore the realized profit. Discussing the performance of the (family) CEO is another example which could be facilitated by an (high quality) audit, as well as discussions regarding the firm's value (e.g. in case a family member wants to buy or sell shares). Therefore, while the role of the board and the auditor could intuitively be considered to be complementary, family firms seem to 'fear' the interference of auditors due to privacy and confidentiality considerations. Auditors could therefore better inform family firms about how much they value confidentiality of information and about how they could assist in discussions that may cause conflicts. Directors, on the other hand, should be more informed about the added value that an external audit can provide to their monitoring tasks.

\subsection{Limitations and future research directions}

There are, of course, some limitations associated with this study that indicate possibilities for future research. In the first place, we only examined whether high quality auditors are demanded to mitigate intrafamily agency conflicts while we did not examine their effectiveness in doing this. Second, while the Big4 proxy for audit quality is used very often in audit demand studies, prior research did not yet examine whether Big4 auditors are also perceived to provide higher quality in a family firm context, especially regarding the 
mitigation of intrafamily agency costs. Third, since this study is a single country study, one should also be careful with generalizing its results and comparing them with others. However, we do not expect large differences between countries regarding how intrafamily agency conflicts could lead to the demand for an (high quality) audit as we expect the influence of contextual factors to be rather limited in this relationship but this needs further examination. The fact that we use data based on single respondents (the CEO) is a fourth limitation of this paper, especially since the CEO will only be able to provide his/her perception about the level of cohesion within the family and about the monitoring effectiveness of the board. While this choice is in line with other studies regarding both family cohesion (e.g. Laghi, Baiocco, Lonigro, Capacchione, \& Baumgartner, 2012; Laghi et al., 2016; Lansberg \& Astrachan, 1994; Sánchez-Queija, Oliva, Parra, \& Camacho, 2016; Wang et al., 2015) and board effectiveness (e.g. Pearce \& Zahra, 1991; Zahra, 1996; Zahra, Neubaum \& Huse, 2000; in: Minichilli et al., 2009) and seems reasonable given the difficulty of gaining access to primary data, especially regarding family relationships (several CEOs reported to us that the items included in the cohesion scale were too personal and therefore confidential), one should take this into account when interpreting the results of this study. Fifth, while the use of family cohesion allowed us to better take into account the heterogeneity of family firms, we were only able to take into account this heterogeneity regarding the level of intrafamily agency conflicts. We relied on the traditional compositional proxies to measure the other types of agency conflicts while they may also require more advanced measures that account for the complexity of family firms. Finally, the different types of agency conflicts may also influence each other (e.g. high levels of cohesion and thus a low level of intrafamily agency conflicts may lead to higher family employment at the expense of firm value and therefore to a higher level of agency conflicts between family and non-family members). We did not take these potential interactions into account while they might reveal additional dynamics regarding the 
demand for auditing and the behavior of family firms in general. Overall, we hope that both our contributions and limitations will motivate other researchers to further examine the topics examined in this study in order to further increase our understanding of how emotions and intrafamily agency conflicts may influence corporate decision making.

\section{References}

Abdel-Khalik, A. R. (1989). Why Do Private Companies Demand Auditing? A Case for Organizational Loss of Control. Journal of Accounting, Auditing \& Finance, 8(1), 3152.

Andrews, M. C., Kacmar, K. M., Blakely, G. L., \& Bucklew, N. S. (2008). Group Cohesion as an Enhancement to the Justice-Affective Commitment Relationship. Group \& Organization Management, 33(6), 736-755.

Ang, J. S., Cole, R. A., \& Lin, J. W. (2000). Agency Costs and Ownership Structure. Journal of Finance, 55(1), 81-106.

Bammens, Y., Voordeckers, W., \& Van Gils, A. (2008). Boards of directors in family firms: a generational perspective. Small Business Economics, 31(2), 163-180.

Bammens, Y., Voordeckers, W., \& Van Gils, A. (2010). Boards of Directors in Family Businesses: A Literature Review and Research Agenda. International Journal of Management Reviews, 13(2), 134-152.

Beasley, M. S., \& Petroni, K. R. (2001). Board Independence and Audit-Firm Type. Auditing, 20(1), 97-114.

Becker, C. L., Defond, M. L., Jiambalvo, J., \& Subramanyam, K. R. (1998). The Effect of Audit Quality on Earnings Management. Contemporary Accounting Research, 15(1), $1-24$.

Berrone, P., Cruz, C., \& Gomez-Mejia, L. R. (2012). Socioemotional Wealth in Family Firms: Theoretical Dimensions, Assessment Approaches, and Agenda for Future Research. Family Business Review, 25(3), 258-279.

Björnberg, A., \& Nicholson, N. (2007). The Family Climate Scales-Development of a New Measure for Use in Family Business Research. Family Business Review, 20(3), 229246.

Blanco-Mazagatos, V., De Quevedo-Puente, E., \& Castrillo, L. A. (2007). The Trade-Off Between Financial Resources and Agency Costs in the Family Business: An Exploratory Study. Family Business Review, 20(3), 199-213.

Boone, J. P., Khurana, I. K., \& Raman, K. K. (2010). Do the Big 4 and the Second-tier firms provide audits of similar quality? Journal of Accounting \& Public Policy, 29(4), 330352.

Brambor, T., Clark, W. R., \& Golder, M. (2006). Understanding interaction models: Improving empirical analyses. Political analysis, 14(1), 63-82.

Burkart, M., Panunzi, F., \& Shleifer, A. (2003). Family Firms. Journal of Finance, 58(5), 2167-2202.

Carcello, J. V., Hermanson, D. R., Neal, T. L., \& Riley Jr, R. A. (2002). Board Characteristics and Audit Fees. Contemporary Accounting Research, 19(3), 365-384. 
Carcello, J. V., Hermanson, D. R., \& Ye, Z. (2011). Corporate Governance Research in Accounting and Auditing: Insights, Practice Implications, and Future Research Directions. Auditing: A Journal of Practice \& Theory, 30(3), 1-31.

Carey, P., Simnett, R., \& Tanewski, G. (2000). Voluntary Demand for Internal and External Auditing by Family Businesses. Auditing: A Journal of Practice \& Theory, 19(1), 3751.

Chen, K. Y., \& Jian, Z. (2007). Audit Committee, Board Characteristics, and Auditor Switch Decisions by Andersen's Clients. Contemporary Accounting Research, 24(4), 10851117.

Chow, C. W. (1982). The Demand for External Auditing: Size, Debt and Ownership Influences. The Accounting Review, 57(2), 272-291.

Chrisman, J. J., Chua, J. H., Kellermanns, F. W., \& Chang, E. P. C. (2007). Are family managers agents or stewards? An exploratory study in privately held family firms. Journal of Business Research, 60(10), 1030-1038.

Chrisman, J. J., Chua, J. H., \& Litz, R. A. (2004). Comparing the Agency Costs of Family and Non-Family Firms: Conceptual Issues and Exploratory Evidence. Entrepreneurship: Theory \& Practice, 28(4), 335-354.

Cohen, J., Krishnamoorthy, G., \& Wright, A. (2004). The Corporate Governance Mosaic and Financial Reporting Quality. Journal of Accounting Literature, 23, 87-152.

Collin, S.-O. Y., \& Ahlberg, J. (2012). Blood in the boardroom: Family relationships influencing the functions of the board. Journal of Family Business Strategy, 3(4), 207219.

Collin, S.-O. Y., Ahlberg, J., Berg, K., Broberg, P., \& Karlsson, A. (2015). The Auditor as Consigliere in Family Firms [working paper].

Collis, J. (2012). Determinants of voluntary audit and voluntary full accounts in micro- and non-micro small companies in the UK. Accounting and Business Research, 42(4), 441-468.

Collis, J., Jarvis, R., \& Skerratt, L. (2004). The demand for the audit in small companies in the UK. Accounting and Business Research, 34(2), 87-100.

Daily, C. M., \& Dollinger, M. J. (1992). An empirical examination of ownership structure in family and professionally managed firms. Family Business Review, 5(2), 117-136.

Davis, W. D., Dibrell, C., Craig, J. B., \& Green, J. (2013). The effects of goal orientation and client feedback on the adaptive behaviors of family enterprise advisors. Family Business Review, 26(3), 215-234.

DeAngelo, L. E. (1981). Auditor Size and Audit Quality. Journal of Accounting \& Economics, 3(3), 183-199.

Dedman, E., Kausar, A., \& Lennox, C. (2014). The Demand for Audit in Private Firms: Recent Large-Sample Evidence from the UK. The European Accounting Review, 23(1), 1-23.

DeFond, M. L. (1992). The Association Between Changes in Client Firm Agency Costs and Auditor Switching. Auditing: A Journal of Practice \& Theory, 11(1), 16-31.

Dyer, W. G. (2003). The Family: The Missing Variable in Organizational Research. Entrepreneurship Theory and Practice, 27(4), 401-416.

Eisenhardt, K. M. (1989). Agency Theory: An Assessment and Review. Academy of Management Review, 14(1), 57-74.

Fama, E. F., \& Jensen, M. C. (1983a). Agency Problems and Residual Claims. Journal of Law \& Economics, 26(2), 327-350.

Fama, E. F., \& Jensen, M. C. (1983b). Separation of Ownership and Control. Journal of Law \& Economics, 26(2), 301-326. 
Fan, J. P. H., \& Wong, T. J. (2005). Do External Auditors Perform a Corporate Governance Role in Emerging Markets? Evidence from East Asia. Journal of Accounting Research, 43(1), 35-72.

Finkelstein, S., \& Mooney, A. C. (2003). Not the usual suspects: How to use board process to make boards better. Academy of Management Executive, 17(2), 101-113.

Firth, M., \& Smith, A. (1992). Selection of auditor firms by companies in the new issue market. Applied Economics, 24(2), 247-255.

Francis, J. R., Maydew, E. L., \& Sparks, H. C. (1999). The Role of Big 6 Auditors in the Credible Reporting of Accruals. Auditing: A Journal of Practice \& Theory, 18(2), 17.

Francis, J. R., Richard, C., \& Vanstraelen, A. (2009). Assessing France's Joint Audit Requirement: Are Two Heads Better than One? Auditing: A Journal of Practice \& Theory, 28(2), 35-63.

Francis, J. R., \& Wilson, E. R. (1988). Auditor Changes: A Joint Test of Theory Relating to Agency Costs and Auditor Differentiation. The Accounting Review, 63(4), 663-682.

Franzese, R., \& Kam, C. (2009). Modeling and interpreting interactive hypotheses in regression analysis: University of Michigan Press.

Gabrielsson, J., \& Winlund, H. (2000). Boards of directors in small and medium-sized industrial firms: examining the effects of the board's working style on board task performance. Entrepreneurship \& Regional Development, 12(4), 311-330.

Gómez-Mejía, L. R., Haynes, K. T., Núñez-Nickel, M., Jacobson, K. J. L., \& MoyanoFuentes, J. (2007). Socioemotional Wealth and Business Risks in Family-controlled Firms: Evidence from Spanish Olive Oil Mills. Administrative Science Quarterly, 52(1), 106-137.

Gomez-Mejia, L. R., Nuñez-Nickel, M., \& Gutierrez, I. (2001). The Role of Family Ties in Agency Contracts. Academy of Management Journal, 44(1), 81-95.

Hope, O.-K., Langli, J. C., \& Thomas, W. B. (2012). Agency conflicts and auditing in private firms. Accounting, Organizations and Society, 37(7), 500-517.

Hu, L. t., \& Bentler, P. M. (1999). Cutoff criteria for fit indexes in covariance structure analysis: Conventional criteria versus new alternatives. Structural equation modeling: a multidisciplinary journal, 6(1), 1-55.

Huse, M. (2005). Accountability and Creating Accountability: a Framework for Exploring Behavioural Perspectives of Corporate Governance. British Journal of Management, $16,65-79$.

Ireland, J. C., \& Lennox, C. S. (2002). The Large Audit Firm Fee Premium: A Case of Selectivity Bias? Journal of Accounting, Auditing \& Finance, 17(1), 73-91.

Jaffe, D. T., Lane, S., Dashew, L., \& Bork, D. (1997). The CPA as family adviser. Journal of accountancy, 183, 42-52.

Jensen, M. C., \& Meckling, W. H. (1976). Theory of the Firm: Managerial Behavior, Agency Costs and Ownership Structure. Journal of Financial Economics, 3(4), 305-360.

Johnson, J. L., Daily, C. M., \& Ellstrand, A. E. (1996). Boards of Directors: A Review and Research Agenda. Journal of Management, 22(3), 409.

Jones, C. D., Makri, M., \& Gomez-Mejia, L. R. (2008). Affiliate Directors and Perceived Risk Bearing in Publicly Traded, Family-Controlled Firms: The Case of Diversification. Entrepreneurship: Theory \& Practice, 32(6), 1007-1026.

Karjalainen, J. (2011). Audit Quality and Cost of Debt Capital for Private Firms: Evidence from Finland. International Journal of Auditing, 15(1), 88-108.

Karra, N., Tracey, P., \& Phillips, N. (2006). Altruism and Agency in the Family Firm: Exploring the Role of Family, Kinship, and Ethnicity. Entrepreneurship: Theory \& Practice, 30(6), 861-877. 
Kellermanns, F. W., Dibrell, C., \& Cruz, C. (2014). The role and impact of emotions in family business strategy: New approaches and paradigms. Journal of Family Business Strategy, 5(3), 277-279.

Kellermanns, F. W., \& Eddleston, K. A. (2004). Feuding Families: When Conflict Does a Family Firm Good. Entrepreneurship: Theory \& Practice, 28(3), 209-228.

Kellermanns, F. W., \& Eddleston, K. A. (2007). A family perspective on when conflict benefits family firm performance. Journal of Business Research, 60(10), 1048-1057.

Klein, H. J., \& Mulvey, P. W. (1995). Two Investigations of the Relationships among Group Goals, Goal Commitment, Cohesion, and Performance. Organizational Behavior and Human Decision Processes, 61(1), 44-53.

Kouneski, E. F. (2000). Studies using FACES and the Circumplex Model.

Laghi, F., Baiocco, R., Lonigro, A., Capacchione, G., \& Baumgartner, E. (2012). Family functioning and binge drinking among Italian adolescents. Journal of Health Psychology, 17(8), 1132-1141.

Laghi, F., McPhie, M. L., Baumgartner, E., Rawana, J. S., Pompili, S., \& Baiocco, R. (2016). Family Functioning and Dysfunctional Eating Among Italian Adolescents: The Moderating Role of Gender. Child Psychiatry \& Human Development, 47(1), 43-52.

Lambrecht, J., \& Lievens, J. (2008). Pruning the Family Tree: An Unexplored Path to Family Business Continuity and Family Harmony. Family Business Review, 21(4), 295-313.

Lansberg, I., \& Astrachan, J. H. (1994). Influence of Family Relationships on Succession Planning and Training: The Importance of Mediating Factors. Family Business Review, 7(1), 39-59.

Lawrence, A., Minutti-Meza, M., \& Zhang, P. (2011). Can Big 4 versus Non-Big 4 Differences in Audit-Quality Proxies Be Attributed to Client Characteristics? The Accounting Review, 86(1), 259-286.

Lennox, C. (2005). Management Ownership and Audit Firm Size. Contemporary Accounting Research, 22(1), 205-227.

Lester, R. H., \& Cannella, A. A. (2006). Interorganizational Familiness: How Family Firms Use Interlocking Directorates to Build Community-Level Social Capital. Entrepreneurship: Theory \& Practice, 30(6), 755-775.

Liu, C.-L., \& Lai, S.-M. (2012). Organizational Complexity and Auditor Quality. Corporate Governance: An International Review, 20(4), 352-368.

Lubatkin, M. H., Schulze, W. S., Ling, Y., \& Dino, R. N. (2005). The effects of parental altruism on the governance of family-managed firms. Journal of Organizational Behavior, 26(3), 313-330.

Michael-Tsabari, N., \& Lavee, Y. (2012). Too close and too rigid: Applying the Circumplex Model of Family Systems to First-Generation Family Firms. Journal of Marital And Family Therapy, 38(Supplement 1), 105-116.

Miller, D., \& Le Breton-Miller, I. (2006). Family Governance and Firm Performance: Agency, Stewardship, and Capabilities. Family Business Review, 19(1), 73-87.

Minichilli, A., Zattoni, A., Nielsen, S., \& Huse, M. (2012). Board task performance: An exploration of micro- and macro-level determinants of board effectiveness. Journal of Organizational Behavior, 33(2), 193-215.

Minichilli, A., Zattoni, A., \& Zona, F. (2009). Making Boards Effective: An Empirical Examination of Board Task Performance. British Journal of Management, 20(1), 5574.

Nicholson, N. (2008a). Evolutionary Psychology and Family Business: A New Synthesis for Theory, Research, and Practice. Family Business Review, 21(1), 103-118.

Nicholson, N. (2008b). Evolutionary Psychology, Organizational Culture, and the Family Firm. Academy of Management Perspectives, 22(2), 73-84. 
Niemi, L., Kinnunen, J., Ojala, H., \& Troberg, P. (2012). Drivers of voluntary audit in Finland: to be or not to be audited? Accounting and Business Research, 42(2), 169196.

Niskanen, M., Karjalainen, J., \& Niskanen, J. (2010). The Role of Auditing in Small, Private Family Firms: Is It About Quality and Credibility? Family Business Review, 23(3), 230-245.

Niskanen, M., Karjalainen, J., \& Niskanen, J. (2011). Demand for Audit Quality in Private Firms: Evidence on Ownership Effects. International Journal of Auditing, 15(1), 4365.

Olson, D. H. (2000). Circumplex Model of Marital and Family Systems. Journal of Family Therapy, 22(2), 144.

Olson, D. H. (2010). Faces IV Manual. Minneapolis.

Olson, D. H. (2011). FACES IV and the Circumplex Model: Validation Study. Journal of Marital And Family Therapy, 37(1), 64-80.

Piot, C. (2001). Agency costs and audit quality: evidence from France. European Accounting Review, 10(3), 461-499.

Reed, B. J., Trombley, M. A., \& Dhaliwal, D. S. (2000). Demand for Audit Quality: The Case of Laventhol and Horwath's Auditees. Journal of Accounting, Auditing \& Finance, 15(2), 183-198.

Salvato, C., \& Moores, K. (2010). Research on Accounting in Family Firms: Past Accomplishments and Future Challenges. Family Business Review, 23(3), 193-215.

Sánchez-Queija, I., Oliva, A., Parra, Á., \& Camacho, C. (2016). Longitudinal Analysis of the Role of Family Functioning in Substance Use. Journal of Child and Family Studies, 25(1), 232-240.

Schepers, J., Voordeckers, W., Steijvers, T., \& Laveren, E. (2014). The entrepreneurial orientation-performance relationship in private family firms: the moderating role of socioemotional wealth. Small Business Economics, 43(1), 39-55.

Schulze, W. S., Lubatkin, M. H., \& Dino, R. N. (2003a). Exploring the Agency Consequences of Ownership Dispersion Among the Directors of Private Family Firms. Academy of Management Journal, 46(2), 179-194.

Schulze, W. S., Lubatkin, M. H., \& Dino, R. N. (2003b). Toward a theory of agency and altruism in family firms. Journal of Business Venturing, 18(4), 473-490.

Schulze, W. S., Lubatkin, M. H., Dino, R. N., \& Buchholtz, A. K. (2001). Agency Relationships in Family Firms: Theory and Evidence. Organization Science, 12(2), 99-116.

Sharma, P., Chrisman, J. J., Pablo, A. L., \& Chua, J. H. (2001). Determinants of Initial Satisfaction with the Succession Process in Family Firms: A Conceptual Model. Entrepreneurship: Theory \& Practice, 25(3), 17.

Songini, L., Gnan, L., \& Malmi, T. (2013). The role and impact of accounting in family business. Journal of Family Business Strategy, 4(2), 71-83.

Steier, L. (2001). Family Firms, Plural Forms of Governance, and the Evolving Role of Trust. Family Business Review, 14(4), 353-368.

Steijvers, T., \& Niskanen, M. (2014). Tax aggressiveness in private family firms: An agency perspective. Journal of Family Business Strategy, 5(4), 347-357.

Su, E., \& Dou, J. (2013). How Does Knowledge Sharing Among Advisors From Different Disciplines Affect the Quality of the Services Provided to the Family Business Client? An Investigation From the Family Business Advisor's Perspective. Family Business Review, 26(3), 256-270. 
Tekleab, A. G., Quigley, N. R., \& Tesluk, P. E. (2009). A Longitudinal Study of Team Conflict, Conflict Management, Cohesion, and Team Effectiveness. Group \& Organization Management, 34(2), 170-205.

Trotman, A. J., \& Trotman, K. T. (2010). The Intersection of Family Business and Audit Research: Potential Opportunities. Family Business Review, 23(3), 216-229.

Vandekerkhof, P., Steijvers, T., Hendriks, W., \& Voordeckers, W. (2015). The Effect of Organizational Characteristics on the Appointment of Nonfamily Managers in Private Family Firms: The Moderating Role of Socioemotional Wealth. Family Business Review, 28(2), 104-122.

Voordeckers, W., Van Gils, A., \& Van den Heuvel, J. (2007). Board Composition in Small and Medium-Sized Family Firms. Journal of Small Business Management, 45(1), 137156.

Wang, Y.-h., Haslam, M., Yu, M., Ding, J., Lu, Q., \& Pan, F. (2015). Family functioning, marital quality and social support in Chinese patients with epilepsy. Health and Quality of Life Outcomes, 13(1), 1-8.

Westhead, P., \& Cowling, M. (1998). Family Firm Research: The Need for a Methodological Rethink. Entrepreneurship: Theory \& Practice, 23(1), 31-56.

Westphal, J. D. (1999). Collaboration in the Boardroom: Behavioral and Performance Consequences of CEO-Board Social Ties. Academy of Management Journal, 42(1), 724.

Willekens, M., \& Achmadi, C. (2003). Pricing and supplier concentration in the private client segment of the audit market: Market power or competition? The International Journal of Accounting, 38(4), 431-455.

Zahra, S. A., \& Pearce, J. A. (1989). Boards of Directors and Corporate Financial Performance: A Review and Integrative Model. Journal of Management, 15(2), 291334.

Zona, F. (2015). Board ownership and processes in family firms. Small Business Economics, 44(1), 105-122.

Zona, F., \& Zattoni, A. (2007). Beyond the Black Box of Demography: board processes and task effectiveness within Italian firms. Corporate Governance: An International Review, 15(5), 852-864. 


\begin{tabular}{|c|c|c|c|c|c|c|c|c|}
\hline & \multirow[b]{3}{*}{ Mean } & \multirow[b]{3}{*}{ Median } & \multirow[b]{3}{*}{ Min } & \multirow[b]{3}{*}{$\operatorname{Max}$} & \multirow[b]{3}{*}{ s.d. } & \multicolumn{3}{|c|}{ BIG4 auditor (yes/no) } \\
\hline & & & & & & Yes (1) & No $(0)$ & (1) vs. (0) \\
\hline & & & & & & Mean & Mean & $p$-Value \\
\hline \multirow{10}{*}{ 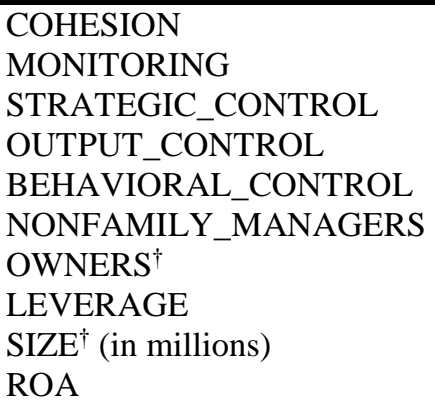 } & 24.77 & 26.00 & -4.00 & 43.00 & 8.61 & 20.40 & 25.15 & $0.09 *$ \\
\hline & 13.72 & 14.00 & 0.00 & 28.00 & 6.65 & 10.70 & 13.98 & 0.13 \\
\hline & 2.06 & 2.00 & 0.00 & 4.00 & 1.18 & 1.90 & 2.08 & 0.65 \\
\hline & 2.08 & 2.00 & 0.00 & 4.00 & 1.05 & 1.53 & 2.13 & $0.08 *$ \\
\hline & 1.80 & 2.00 & 0.00 & 4.00 & 1.00 & 1.40 & 1.84 & 0.18 \\
\hline & 0.48 & 0.50 & 0.00 & 0.93 & 0.28 & 0.77 & 0.46 & $0.00 * * *$ \\
\hline & 3.68 & 3.00 & 1.00 & 25.00 & 3.92 & 4.80 & 3.58 & 0.35 \\
\hline & 0.61 & 0.65 & 0.03 & 0.97 & 0.22 & 0.59 & 0.61 & 0.84 \\
\hline & 14.78 & 8.15 & 2.45 & 104.88 & 18.34 & 40.41 & 12.56 & $0.00 * * *$ \\
\hline & 0.06 & 0.04 & -0.08 & 0.29 & 0.07 & 0.05 & 0.06 & 0.74 \\
\hline \multirow{4}{*}{$\begin{array}{l}\text { GROUP } \\
\text { INDUSTRY } \\
\text { BIG4 }\end{array}$} & Prop. & & & & & Prop. & Prop. & $p$-Value \\
\hline & 0.33 & & & & & 0.50 & 0.31 & 0.23 \\
\hline & 0.51 & & & & & 0.60 & 0.50 & 0.56 \\
\hline & 0.08 & & & & & & & \\
\hline
\end{tabular}

$\mathrm{n}=125 ; *, * *, * * *$ indicate significance at the $10 \%, 5 \%$ and $1 \%$ levels respectively (two-tailed).

${ }^{\dagger}$ The natural logarithm of this variable is used in our statistical analysis.

Notes: This table presents the descriptive statistics (means or proportions, medians, minima, maxima and standard deviations) of the variables used to test our hypotheses. Moreover, this table compares the means (or proportions for the variables GROUP and INDUSTRY) of each variable between the firms that hired a BIG4 auditor and those that did not. 
Table 2. Correlation matrix

\begin{tabular}{|c|c|c|c|c|c|c|c|c|c|c|c|c|c|}
\hline Variable & 1 & 2 & 3 & 4 & 5 & 6 & 7 & 8 & 9 & 10 & 11 & 12 & 13 \\
\hline 1. BIG4 & 1.00 & $-0.16^{*}$ & -0.12 & -0.03 & -0.13 & -0.13 & $0.34^{* * * *}$ & $-0.15^{*}$ & -0.05 & $0.26^{* * *}$ & -0.04 & 0.11 & 0.05 \\
\hline 2. COHESION & $-0.15^{*}$ & 1.00 & 0.09 & 0.14 & 0.13 & 0.00 & -0.09 & 0.04 & $0.15^{*}$ & 0.02 & 0.06 & -0.01 & -0.14 \\
\hline 3. MONITORING & -0.13 & 0.05 & 1.00 & $0.75^{* * *}$ & $0.92^{* * *}$ & $0.90^{* * * *}$ & $-0.23^{* *}$ & -0.06 & 0.03 & -0.03 & -0.05 & -0.01 & -0.01 \\
\hline 4. STRATEGIC_CONTROL & -0.04 & 0.11 & $0.75^{* * *}$ & 1.00 & $0.62^{* * * *}$ & $0.59^{* * *}$ & -0.03 & $-0.15^{*}$ & 0.01 & 0.06 & -0.07 & 0.05 & 0.01 \\
\hline 5. OUTPUT_CONTROL & $-0.16^{*}$ & 0.09 & $0.95^{* * * *}$ & $0.63^{* * *}$ & 1.00 & $0.74^{* * * *}$ & $-0.26^{* * *}$ & -0.07 & 0.10 & -0.04 & -0.01 & -0.07 & -0.02 \\
\hline 6. BEHAVIORAL_CONTROL & -0.12 & -0.03 & $0.94^{* * * *}$ & $0.60^{* * *}$ & $0.80^{* * *}$ & 1.00 & $-0.22^{* *}$ & -0.02 & -0.07 & -0.03 & -0.04 & 0.05 & 0.04 \\
\hline 7. NONFAMILY_MANAGERS & $0.31^{* * *}$ & 0.04 & $-0.20^{* *}$ & -0.01 & $-0.23^{* * *}$ & $-0.19^{* *}$ & 1.00 & 0.03 & 0.07 & $0.21^{* *}$ & $-0.19^{* *}$ & 0.10 & 0.08 \\
\hline 8. OWNERS & -0.07 & 0.02 & -0.10 & $-0.16^{*}$ & -0.10 & -0.05 & 0.03 & 1.00 & -0.12 & -0.03 & 0.03 & -0.04 & -0.10 \\
\hline 9. LEVERAGE & -0.02 & 0.14 & 0.02 & 0.00 & 0.09 & -0.06 & 0.13 & -0.07 & 1.00 & $-0.19^{* *}$ & $-0.30^{* * *}$ & -0.08 & $-0.21^{* *}$ \\
\hline 10. SIZE & $0.35^{* * *}$ & 0.01 & 0.03 & 0.12 & -0.02 & 0.03 & $0.27^{* * * *}$ & -0.12 & $-0.25^{* * *}$ & 1.00 & 0.03 & 0.01 & -0.02 \\
\hline 11. ROA & -0.03 & -0.05 & -0.06 & -0.08 & -0.04 & -0.07 & $-0.15^{*}$ & 0.01 & $-0.29^{* * *}$ & 0.05 & 1.00 & -0.14 & 0.08 \\
\hline 12. GROUP & 0.11 & 0.01 & 0.00 & 0.06 & -0.06 & 0.04 & 0.10 & -0.07 & -0.08 & 0.02 & -0.13 & 1.00 & -0.07 \\
\hline 13. INDUSTRY & 0.05 & $-0.20^{* *}$ & 0.00 & 0.01 & -0.02 & 0.03 & 0.08 & -0.08 & $-0.19^{* *}$ & 0.00 & 0.10 & -0.07 & 1.00 \\
\hline
\end{tabular}

$\mathrm{n}=125 ; *, * *, * * *$ indicate significance at the $10 \%, 5 \%$ and $1 \%$ levels respectively (two-tailed). The Pearson correlations are reported below the diagonal, the Spearman correlations above the diagonal. 
Table 3. Logistic regression results

\begin{tabular}{|c|c|c|c|c|c|}
\hline Model & 1 & 2 & 3 & 4 & 5 \\
\hline \multirow{3}{*}{$\begin{array}{l}\text { Dependent variable: } \\
\text { Explanatory variables: }\end{array}$} & BIG4 & BIG4 & BIG4 & BIG4 & BIG4 \\
\hline & & & & & \\
\hline & $\begin{array}{l}-0.1337 * * * \\
(0.0401)\end{array}$ & $\begin{array}{l}-0.5173 * * * \\
(0.1849)\end{array}$ & $\begin{array}{l}-0.2699 * * \\
(0.1198)\end{array}$ & $\begin{array}{l}-0.5063 * * * \\
(0.1753)\end{array}$ & $\begin{array}{l}-0.4665 * * * \\
(0.1328)\end{array}$ \\
\hline MONITORING & & $\begin{array}{l}-0.7742 * * \\
(0.3868)\end{array}$ & & & \\
\hline $\begin{array}{l}\text { COHESION* } \\
\text { MONITORING }\end{array}$ & & $\begin{array}{l}0.0289 * * \\
(0.0144)\end{array}$ & & & \\
\hline STRATEGIC_CONTROL & & & $\begin{array}{l}-1.9389 \\
(1.2868)\end{array}$ & & \\
\hline $\begin{array}{l}\text { COHESION* } \\
\text { STRATEGIC_CONTROL }\end{array}$ & & & $\begin{array}{c}0.0581 \\
(0.0453)\end{array}$ & & \\
\hline OUTPUT_CONTROL & & & & $\begin{array}{l}-4.8792 * \\
(2.6041)\end{array}$ & \\
\hline $\begin{array}{l}\text { COHESION* } \\
\text { OUTPUT_CONTROL }\end{array}$ & & & & $\begin{array}{l}0.1917 * * \\
(0.0933)\end{array}$ & \\
\hline BEHAVIORAL_CONTROL & & & & & $\begin{array}{l}-4.7962 * * * \\
(1.7765)\end{array}$ \\
\hline $\begin{array}{l}\text { COHESION* } \\
\quad \text { BEHAVIORAL_CONTROL }\end{array}$ & & & & & $\begin{array}{l}0.1756^{* *} \\
(0.0745)\end{array}$ \\
\hline Control variables: & & & & & \\
\hline NONFAMILY_MANAGERS & $\begin{array}{l}5.5314 * * * \\
(1.8245)\end{array}$ & $\begin{array}{l}4.4298 * * * \\
(1.6518)\end{array}$ & $\begin{array}{l}6.0032 * * * \\
(2.2366)\end{array}$ & $\begin{array}{l}4.4615 * * \\
(1.7700)\end{array}$ & $\begin{array}{l}4.5933 * * * \\
(1.5921)\end{array}$ \\
\hline OWNERS & $\begin{array}{c}0.1640 \\
(0.5761)\end{array}$ & $\begin{array}{l}-0.1046 \\
(0.5874)\end{array}$ & $\begin{array}{l}-0.0688 \\
(0.4693)\end{array}$ & $\begin{array}{l}-0.0535 \\
(0.5729)\end{array}$ & $\begin{array}{l}-0.0938 \\
(0.6335)\end{array}$ \\
\hline LEVERAGE & $\begin{array}{l}3.7548 * \\
(2.0840)\end{array}$ & $\begin{array}{l}4.6560 * * \\
(2.0816)\end{array}$ & $\begin{array}{l}5.1364 * * \\
(2.0111)\end{array}$ & $\begin{array}{l}4.0177 * * \\
(2.0292)\end{array}$ & $\begin{array}{l}4.2452 * * \\
(2.1160)\end{array}$ \\
\hline SIZE & $\begin{array}{l}1.6221 * * * \\
(0.5228)\end{array}$ & $\begin{array}{l}1.8896 * * \\
(0.8184)\end{array}$ & $\begin{array}{l}1.8974 * * \\
(0.7633)\end{array}$ & $\begin{array}{l}1.8112 * * \\
(0.7572)\end{array}$ & $\begin{array}{l}1.8973 * * * \\
(0.7390)\end{array}$ \\
\hline ROA & $\begin{array}{c}2.3872 \\
(4.7363)\end{array}$ & $\begin{array}{l}-9.6544 \\
(9.1485)\end{array}$ & $\begin{array}{l}-0.7790 \\
(5.3551)\end{array}$ & $\begin{array}{l}-8.7804 \\
(8.7865)\end{array}$ & $\begin{array}{l}-6.1199 \\
(6.4439)\end{array}$ \\
\hline GROUP & $\begin{array}{l}1.5030 * * \\
(0.6695)\end{array}$ & $\begin{array}{l}1.4813 * * \\
(0.6692)\end{array}$ & $\begin{array}{l}1.3591 * * \\
(0.6748)\end{array}$ & $\begin{array}{l}1.6391 * * \\
(0.6676)\end{array}$ & $\begin{array}{l}1.5104 * * \\
(0.7164)\end{array}$ \\
\hline INDUSTRY & $\begin{array}{c}0.1149 \\
(0.9255)\end{array}$ & $\begin{array}{c}0.8640 \\
(0.8712)\end{array}$ & $\begin{array}{c}0.6987 \\
(0.9211)\end{array}$ & $\begin{array}{c}0.8419 \\
(0.8879)\end{array}$ & $\begin{array}{c}0.6079 \\
(0.9427)\end{array}$ \\
\hline Intercept & $\begin{array}{l}-21.9430 * * * \\
(5.5352)\end{array}$ & $\begin{array}{c}-14.1351 * * \\
(6.0646)\end{array}$ & $\begin{array}{l}-21.4508 * * * \\
(7.7285)\end{array}$ & $\begin{array}{l}-13.8812 * * * \\
(4.8707)\end{array}$ & $\begin{array}{l}-15.2641^{* *} \\
(6.8522)\end{array}$ \\
\hline Log likelihood & -20.3928 & -16.8780 & -18.9359 & -16.9773 & -17.0892 \\
\hline Chi-square & $28.65 * * *$ & $52.94 * * *$ & $23.91 * * *$ & $64.11 * * *$ & $38.98 * * *$ \\
\hline McFadden $\mathrm{R}^{2}$ & 0.4148 & 0.5156 & 0.4566 & 0.5128 & 0.5096 \\
\hline
\end{tabular}

$\mathrm{n}=125 ; *, * *, * * *$ indicate significance at the $10 \%, 5 \%$ and $1 \%$ levels respectively (two-tailed).

Notes: This table presents our logistic (logit) regression results. Both the beta coefficients and the robust standard errors (between brackets) are reported per variable for each model. In this table, also the Log likelihood and the Chi-square statistics are reported for each model, as well as the McFadden $\mathrm{R}^{2}$. 
Table 4a. Additional logistic regression results

\begin{tabular}{|c|c|c|c|c|c|c|c|c|}
\hline Model & 1 & $\mathbf{2 a}$ & $2 \mathbf{b}$ & $3 \mathbf{a}$ & 3b & $4 \mathbf{a}$ & $4 b$ & 5 \\
\hline Dependent variable: & BIG4 & $\begin{array}{l}\text { BIG4 \& } \\
\text { BDO }\end{array}$ & $\begin{array}{l}\text { BIG4 \& } \\
\text { BDO }\end{array}$ & BIG4 & BIG4 & BIG4 & BIG4 & BIG4 \\
\hline \multicolumn{9}{|l|}{ Explanatory variables: } \\
\hline COHESION & $\begin{array}{c}-0.09^{* * *} \\
(0.03)\end{array}$ & $\begin{array}{l}-0.09^{* * *} \\
(0.03)\end{array}$ & $\begin{array}{l}-0.32^{* * *} \\
(0.10)\end{array}$ & & & & & \\
\hline COHESION_ADJ & & & & $\begin{array}{l}-0.18^{* * *} \\
(0.05)\end{array}$ & $\begin{array}{l}-0.60^{* * *} \\
(0.18)\end{array}$ & & & \\
\hline GENERATION & & & & & & $\begin{array}{c}0.36 \\
(0.27)\end{array}$ & $\begin{array}{c}0.76 \\
(0.58)\end{array}$ & \\
\hline MONITORING & & & $\begin{array}{l}-0.47^{* * *} \\
(0.17)\end{array}$ & & $\begin{array}{l}-0.89^{* *} \\
(0.39)\end{array}$ & & $\begin{array}{l}-0.05 \\
(0.13)\end{array}$ & \\
\hline $\begin{array}{l}\text { COHESION* } \\
\text { MONITORING }\end{array}$ & & & $\begin{array}{l}0.02^{* * *} \\
(0.01)\end{array}$ & & & & & \\
\hline $\begin{array}{c}\text { COHESION_ADJ* } \\
\text { MONITORING }\end{array}$ & & & & & $\begin{array}{l}0.03^{* *} \\
(0.01)\end{array}$ & & & \\
\hline $\begin{array}{l}\text { GENERATION* } \\
\text { MONITORING }\end{array}$ & & & & & & & $\begin{array}{l}-0.02 \\
(0.04)\end{array}$ & \\
\hline $\begin{array}{l}\text { COHESION* } \\
\text { FAMILY_BOARD }\end{array}$ & & & & & & & & $\begin{array}{l}-0.12^{* * *} \\
(0.04)\end{array}$ \\
\hline $\begin{array}{l}\text { COHESION* } \\
\quad \text { NONFAMILY_BOARD }\end{array}$ & & & & & & & & $\begin{array}{l}-0.13^{* * * *} \\
(0.04)\end{array}$ \\
\hline \multicolumn{9}{|l|}{ Control variables: } \\
\hline NONFAMILY_MANAGERS & $\begin{array}{l}2.64^{* *} \\
(1.32)\end{array}$ & $\begin{array}{l}4.51^{* *} \\
(1.94)\end{array}$ & $\begin{array}{l}3.88^{* *} \\
(1.88)\end{array}$ & $\begin{array}{l}5.52^{* * *} \\
(1.81)\end{array}$ & $\begin{array}{l}4.62^{* *} \\
(1.81)\end{array}$ & $\begin{array}{l}6.41^{* *} \\
(2.79)\end{array}$ & $\begin{array}{l}5.38^{* *} \\
(2.44)\end{array}$ & $\begin{array}{l}5.78^{* * * *} \\
(2.22)\end{array}$ \\
\hline OWNERS & $\begin{array}{l}-0.05 \\
(0.58)\end{array}$ & $\begin{array}{c}0.10 \\
(0.51)\end{array}$ & $\begin{array}{l}-0.14 \\
(0.49)\end{array}$ & $\begin{array}{c}0.17 \\
(0.60)\end{array}$ & $\begin{array}{c}0.07 \\
(0.57)\end{array}$ & $\begin{array}{c}0.04 \\
(0.58)\end{array}$ & $\begin{array}{l}-0.19 \\
(0.52)\end{array}$ & $\begin{array}{c}0.10 \\
(0.52)\end{array}$ \\
\hline LEVERAGE & $\begin{array}{c}1.94 \\
(1.76)\end{array}$ & $\begin{array}{l}4.43^{* *} \\
(2.06)\end{array}$ & $\begin{array}{l}5.24^{* *} \\
(2.05)\end{array}$ & $\begin{array}{c}3.88^{*} \\
(2.06)\end{array}$ & $\begin{array}{c}4.51^{* *} \\
(1.86)\end{array}$ & $\begin{array}{c}1.41 \\
(2.26)\end{array}$ & $\begin{array}{c}2.01 \\
(1.99)\end{array}$ & $\begin{array}{c}2.28 \\
(2.91)\end{array}$ \\
\hline SIZE & $\begin{array}{l}1.37^{\text {**** }} \\
(0.43)\end{array}$ & $\begin{array}{l}1.33^{\text {**** }} \\
(0.37)\end{array}$ & $\begin{array}{l}1.50^{* * * *} \\
(0.46)\end{array}$ & $\begin{array}{l}1.64^{* * * *} \\
(0.55)\end{array}$ & $\begin{array}{c}1.84^{* *} \\
(0.76)\end{array}$ & $\begin{array}{c}1.00^{* *} \\
(0.42)\end{array}$ & $\begin{array}{c}1.13^{* *} \\
(0.54)\end{array}$ & $\begin{array}{l}1.62^{\text {**** }} \\
(0.49)\end{array}$ \\
\hline ROA & $\begin{array}{l}-4.52 \\
(5.48)\end{array}$ & $\begin{array}{c}0.69 \\
(4.75)\end{array}$ & $\begin{array}{l}-4.35 \\
(5.68)\end{array}$ & $\begin{array}{c}2.38 \\
(4.65)\end{array}$ & $\begin{array}{l}-7.09 \\
(6.84)\end{array}$ & $\begin{array}{c}1.24 \\
(5.52)\end{array}$ & $\begin{array}{c}1.43 \\
(5.21)\end{array}$ & $\begin{array}{c}3.86 \\
(6.78)\end{array}$ \\
\hline GROUP & $\begin{array}{c}0.54 \\
(0.65)\end{array}$ & $\begin{array}{c}1.40^{*} \\
(0.73)\end{array}$ & $\begin{array}{c}1.36^{*} \\
(0.74)\end{array}$ & $\begin{array}{c}1.44^{* * *} \\
(0.68)\end{array}$ & $\begin{array}{c}1.43^{* * *} \\
(0.61)\end{array}$ & $\begin{array}{c}0.98 \\
(0.69)\end{array}$ & $\begin{array}{c}0.97 \\
(0.70)\end{array}$ & $\begin{array}{c}1.92^{* * *} \\
(0.88)\end{array}$ \\
\hline INDUSTRY & $\begin{array}{c}0.10 \\
(0.72)\end{array}$ & $\begin{array}{l}1.32 \\
(0.87)\end{array}$ & $\begin{array}{l}1.89^{* *} \\
(0.89)\end{array}$ & $\begin{array}{l}0.17 \\
(0.93)\end{array}$ & $\begin{array}{c}0.91 \\
(0.89)\end{array}$ & $\begin{array}{l}0.25 \\
(0.90)\end{array}$ & $\begin{array}{c}0.41 \\
(0.90)\end{array}$ & $\begin{array}{c}0.45 \\
(0.92)\end{array}$ \\
\hline Intercept & $\begin{array}{c}-16.16^{* * * *} \\
(5.07)\end{array}$ & $\begin{array}{c}-19.78^{* * *} \\
(4.64)\end{array}$ & $\begin{array}{c}-15.00^{* * * *} \\
(4.81)\end{array}$ & $\begin{array}{c}-20.83^{* * *} \\
(5.38)\end{array}$ & $\begin{array}{r}-11.11^{*} \\
(5.98)\end{array}$ & $\begin{array}{c}-18.14^{* * *} \\
(3.87)\end{array}$ & $\begin{array}{c}-18.41^{* * * *} \\
(4.79)\end{array}$ & $\begin{array}{c}-21.57^{* * * *} \\
(5.54)\end{array}$ \\
\hline Log likelihood & -32.48 & -28.21 & -25.48 & -20.53 & -17.73 & -22.16 & -21.31 & -18.38 \\
\hline Chi-square & $16.24^{* *}$ & $24.74^{* * *}$ & $32.94^{* * *}$ & $32.10^{* * *}$ & $59.86^{* * *}$ & $35.58^{* * *}$ & $33.23^{* * *}$ & $31.44^{* * *}$ \\
\hline McFadden $\mathrm{R}^{2}$ & 0.29 & 0.36 & 0.42 & 0.41 & 0.49 & 0.36 & 0.38 & 0.45 \\
\hline $\mathrm{n}$ & 170 & 125 & 125 & 125 & 125 & 122 & 122 & 106 \\
\hline
\end{tabular}

$*, * *, * * *$ indicate significance at the $10 \%, 5 \%$ and $1 \%$ levels respectively (two-tailed).

Notes: This table presents our additional logistic (logit) regression results. Both the beta coefficients and the robust standard errors (between brackets) are reported per variable for each model. In this table, also the Log likelihood, the Chi-square statistic and the McFadden $\mathrm{R}^{2}$ are reported for each model, as well as the number of cases included. 
Table 4b. Additional logistic regression results (continued)

\begin{tabular}{|c|c|c|c|c|c|c|c|c|}
\hline Model & 6 & $7 \mathbf{a}$ & $7 \mathbf{b}$ & 7c & $\mathbf{8 a}$ & $\mathbf{8 b}$ & $\mathbf{9 a}$ & 9b \\
\hline Dependent variable: & BIG4 & BIG4 & BIG4 & BIG4 & BIG4 & BIG4 & BIG4 & BIG4 \\
\hline \multicolumn{9}{|l|}{ Explanatory variables: } \\
\hline COHESION & $\begin{array}{l}-0.50^{* * * *} \\
(0.18)\end{array}$ & $\begin{array}{l}-0.30^{* *} \\
(0.12)\end{array}$ & $\begin{array}{l}-0.49^{* *} \\
(0.19)\end{array}$ & $\begin{array}{l}-0.37^{* * *} \\
(0.12)\end{array}$ & $\begin{array}{l}-0.09^{* *} \\
(0.04)\end{array}$ & $\begin{array}{l}-0.46^{* *} \\
(0.20)\end{array}$ & $\begin{array}{l}-0.20^{* * *} \\
(0.07)\end{array}$ & $\begin{array}{l}-0.20^{* * *} \\
(0.07)\end{array}$ \\
\hline MONITORING & & & & & & $\begin{array}{l}-0.65^{*} \\
(0.34)\end{array}$ & & \\
\hline MONITORING_ALT & $\begin{array}{l}-1.00^{* *} \\
(0.43)\end{array}$ & & & & & & & \\
\hline DECISIONMAKING_CONTROL & & $\begin{array}{l}-1.32^{*} \\
(0.76)\end{array}$ & & & & & & \\
\hline PERFORMANCE_CONTROL & & & $\begin{array}{l}-2.43^{* *} \\
(1.12)\end{array}$ & & & & & \\
\hline DECISION_CONTROL & & & & $\begin{array}{l}-1.95^{* *} \\
(0.78)\end{array}$ & & & & \\
\hline $\begin{array}{l}\text { COHESION* } \\
\quad \text { MONITORING }\end{array}$ & & & & & & $\begin{array}{l}0.03^{* *} \\
(0.01)\end{array}$ & & \\
\hline $\begin{array}{l}\text { COHESION* } \\
\quad \text { MONITORING_ALT }\end{array}$ & $\begin{array}{c}0.03^{*} \\
(0.02)\end{array}$ & & & & & & & \\
\hline $\begin{array}{l}\text { COHESION* } \\
\quad \text { DECISIONMAKING_CONTROL }\end{array}$ & & $\begin{array}{c}0.05 \\
(0.03)\end{array}$ & & & & & & \\
\hline $\begin{array}{l}\text { COHESION* } \\
\quad \text { PERFORMANCE_CONTROL }\end{array}$ & & & $\begin{array}{l}0.09^{* *} \\
(0.05)\end{array}$ & & & & & \\
\hline $\begin{array}{l}\text { COHESION* } \\
\text { DECISION_CONTROL }\end{array}$ & & & & $\begin{array}{l}0.06^{* *} \\
(0.03)\end{array}$ & & & & \\
\hline \multicolumn{9}{|l|}{ Control variables: } \\
\hline NONFAMILY_MANAGERS & $\begin{array}{l}5.54^{* * * *} \\
(1.97)\end{array}$ & $\begin{array}{l}5.16^{* * *} \\
(1.78)\end{array}$ & $\begin{array}{l}5.81^{* * *} \\
(2.21)\end{array}$ & $\begin{array}{c}5.82^{* * * *} \\
(1.84)\end{array}$ & & & $\begin{array}{c}5.78^{* * *} \\
(2.26)\end{array}$ & $\begin{array}{l}6.14^{* * *} \\
(2.10)\end{array}$ \\
\hline FAMILY_OWNERSHIP & & & & & $\begin{array}{l}-0.02 \\
(0.02)\end{array}$ & $\begin{array}{l}-0.03 \\
(0.02)\end{array}$ & & \\
\hline OWNERS & $\begin{array}{l}-0.10 \\
(0.62)\end{array}$ & $\begin{array}{l}-0.04 \\
(0.62)\end{array}$ & $\begin{array}{l}-0.22 \\
(0.55)\end{array}$ & $\begin{array}{c}0.00 \\
(0.64)\end{array}$ & $\begin{array}{l}-0.11 \\
(0.70)\end{array}$ & $\begin{array}{l}-0.21 \\
(0.54)\end{array}$ & $\begin{array}{l}-0.70 \\
(1.20)\end{array}$ & $\begin{array}{l}-0.96 \\
(1.40)\end{array}$ \\
\hline LEVERAGE & $\begin{array}{l}4.88^{* *} \\
(2.33)\end{array}$ & $\begin{array}{c}4.01^{*} \\
(2.15)\end{array}$ & $\begin{array}{l}4.36^{* *} \\
(2.07)\end{array}$ & $\begin{array}{l}4.45^{* *} \\
(2.21)\end{array}$ & $\begin{array}{c}1.63 \\
(1.56)\end{array}$ & $\begin{array}{c}2.96 \\
(1.88)\end{array}$ & $\begin{array}{c}4.39^{*} \\
(2.56)\end{array}$ & $\begin{array}{c}4.08 \\
(2.51)\end{array}$ \\
\hline SIZE & $\begin{array}{l}2.01^{* * * *} \\
(0.65)\end{array}$ & $\begin{array}{l}1.69^{* * * *} \\
(0.55)\end{array}$ & $\begin{array}{l}1.93^{* * *} \\
(0.62)\end{array}$ & $\begin{array}{l}1.79^{* * * *} \\
(0.58)\end{array}$ & $\begin{array}{l}1.57^{* * * *} \\
(0.54)\end{array}$ & $\begin{array}{c}1.82^{* *} \\
(0.75)\end{array}$ & $\begin{array}{l}1.99^{* * * *} \\
(0.76)\end{array}$ & $\begin{array}{c}1.58^{*} \\
(0.88)\end{array}$ \\
\hline ROA & $\begin{array}{l}-0.94 \\
(4.71)\end{array}$ & $\begin{array}{c}1.55 \\
(4.90)\end{array}$ & $\begin{array}{c}0.26 \\
(4.54)\end{array}$ & $\begin{array}{l}-0.02 \\
(4.61)\end{array}$ & $\begin{array}{l}-6.69 \\
(4.98)\end{array}$ & $\begin{array}{r}-17.32^{*} \\
(9.77)\end{array}$ & $\begin{array}{c}3.74 \\
(6.86)\end{array}$ & $\begin{array}{c}4.00 \\
(6.79)\end{array}$ \\
\hline GROUP & $\begin{array}{c}1.72^{\text {*** }} \\
(0.67)\end{array}$ & $\begin{array}{c}1.57^{* *} \\
(0.65)\end{array}$ & $\begin{array}{c}1.42^{*} \\
(0.76)\end{array}$ & $\begin{array}{c}1.59^{* *} \\
(0.67)\end{array}$ & $\begin{array}{c}0.60 \\
(0.66)\end{array}$ & $\begin{array}{c}0.51 \\
(0.71)\end{array}$ & $\begin{array}{l}1.67^{\text {*** }} \\
(0.64)\end{array}$ & $\begin{array}{c}1.53^{* *} \\
(0.62)\end{array}$ \\
\hline INDUSTRY & $\begin{array}{c}0.37 \\
(1.00)\end{array}$ & $\begin{array}{c}0.15 \\
(0.95)\end{array}$ & $\begin{array}{c}0.41 \\
(0.94)\end{array}$ & $\begin{array}{c}0.29 \\
(0.94)\end{array}$ & $\begin{array}{c}0.49 \\
(0.73)\end{array}$ & $\begin{array}{c}1.17^{*} \\
(0.67)\end{array}$ & $\begin{array}{l}-1.32 \\
(0.90)\end{array}$ & $\begin{array}{l}-1.34 \\
(0.85)\end{array}$ \\
\hline Intercept & $\begin{array}{c}-15.98^{* * *} \\
(6.48)\end{array}$ & $\begin{array}{c}-17.68^{* * * *} \\
(5.98)\end{array}$ & $\begin{array}{c}-16.27^{\text {**** }} \\
(5.68)\end{array}$ & $\begin{array}{c}-17.21^{\text {**** }} \\
(5.93)\end{array}$ & $\begin{array}{c}-14.29^{* * * *} \\
(4.83)\end{array}$ & $\begin{array}{l}-7.61^{*} \\
(4.61)\end{array}$ & $\begin{array}{c}-23.53^{\text {**** }} \\
(8.39)\end{array}$ & $\begin{array}{r}-18.86^{*} \\
(9.62)\end{array}$ \\
\hline Log likelihood & -18.75 & -19.82 & -18.32 & -19.44 & -27.78 & -23.76 & -12.21 & -11.83 \\
\hline Chi-square & $23.27^{* * *}$ & $36.69^{* * *}$ & $18.86^{* *}$ & $34.45^{* * *}$ & $18.24^{* *}$ & $17.84^{*}$ & $22.79^{* * *}$ & $24.23^{* * *}$ \\
\hline McFadden $\mathrm{R}^{2}$ & 0.46 & 0.43 & 0.47 & 0.44 & 0.25 & 0.36 & 0.49 & 0.48 \\
\hline $\mathrm{n}$ & 125 & 125 & 125 & 125 & 125 & 125 & 63 & 54 \\
\hline
\end{tabular}

$*, * *, * * *$ indicate significance at the $10 \%, 5 \%$ and $1 \%$ levels respectively (two-tailed).

Notes: This table presents our additional logistic (logit) regression results. Both the beta coefficients and the robust standard errors (between brackets) are reported per variable for each model. In this table, also the Log likelihood, the Chi-square statistic and the McFadden $\mathrm{R}^{2}$ are reported for each model, as well as the number of cases included. 
Figure 1. Marginal effect of cohesion on audit quality demand as the board's monitoring effectiveness changes

Marginal effect of cohesion as the board's monitoring effectiveness changes Dependent variable: Big4

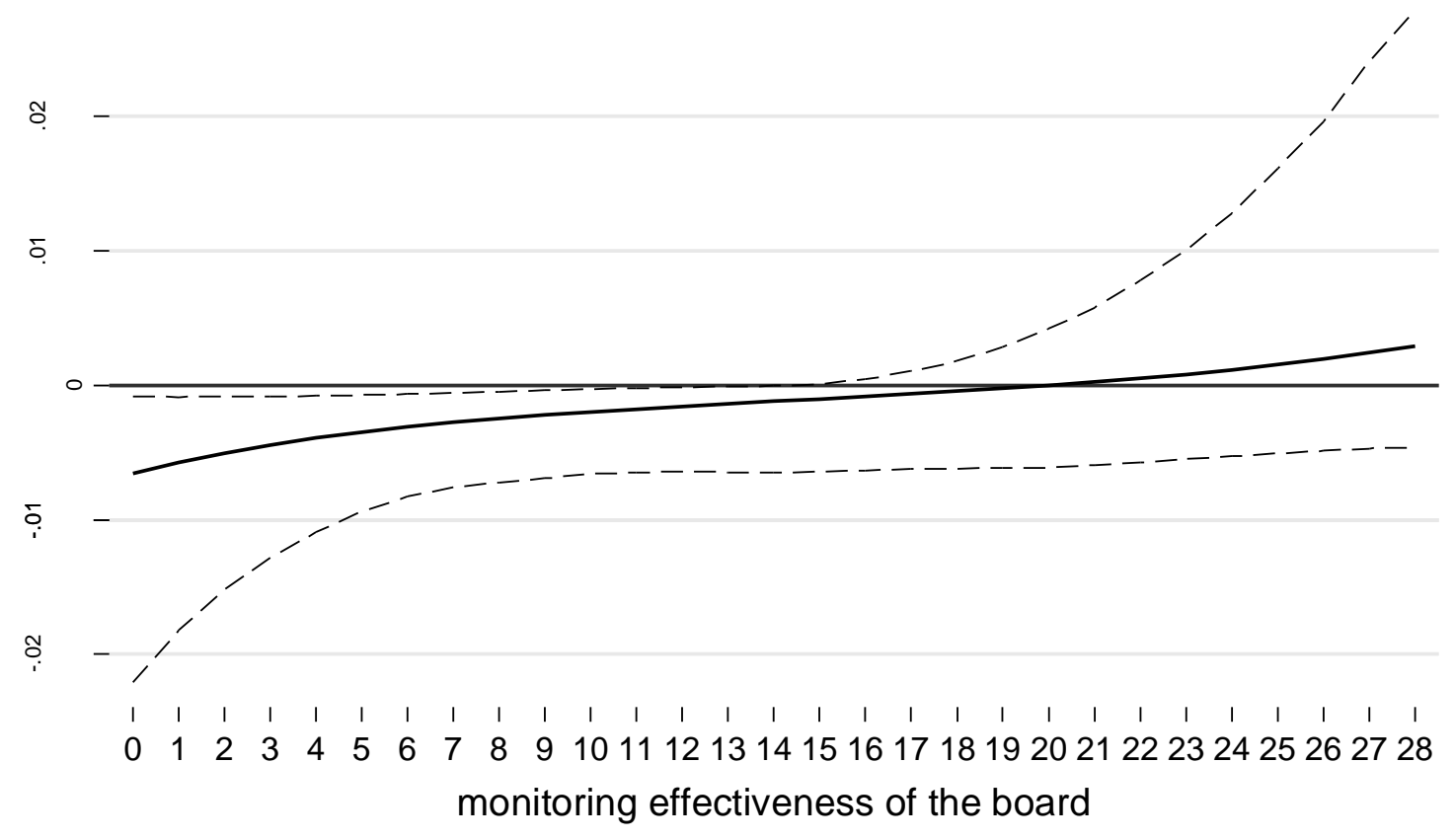

